Faculty Scholarship

2008

\title{
Tax My Ride: Taxing Commuters in Our National Economy
}

Morgan Holcomb

Mitchell Hamline School of Law, morgan.holcomb@mitchellhamline.edu

Publication Information

8 Florida Tax Review 885 (2008)

\section{Repository Citation}

Holcomb, Morgan, "Tax My Ride: Taxing Commuters in Our National Economy" (2008). Faculty Scholarship. Paper 375.

http://open.mitchellhamline.edu/facsch/375

This Article is brought to you for free and open access by Mitchell Hamline Open Access. It has been accepted for inclusion in Faculty Scholarship by an authorized administrator of Mitchell Hamline Open Access. For more information, please contact sean.felhofer@mitchellhamline.edu.

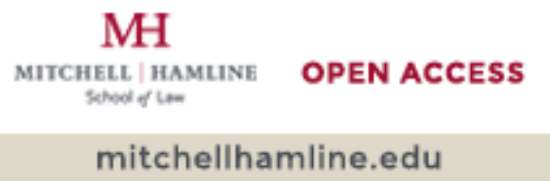




\title{
Tax My Ride: Taxing Commuters in Our National Economy
}

\begin{abstract}
States constitutionally impose individual income taxes on two bases: (1) Residency: a state of residence can tax its residents and domiciliaries and (2) Source: the state in which income is earned can tax the individual earner. At present, there is no articulated constitutional barrier to "double taxation" of individual income. That is, there is no requirement that the source state and residence state collaborate to tax no more than $100 \%$ of an individual's income, and there is no requirement that only one state consider itself the "source" of a particular item of income. In the realm of corporate income taxation the Commerce Clause has been interpreted as requiring each state to tax only the income fairly apportioned to that state. This article argues that the commerce clause applies to check the discriminatory taxation of individual income as well. In addition, the article synthesizes the goals of the Privileges and Immunities Clause with those of the dormant Commerce Clause, and demonstrates that the Privileges and Immunities Clause does not occupy the field to the exclusion of the dormant Commerce Clause. In fact, even absent application of the dormant Commerce Clause, the article posits a separate, arguably more fundamental rationale to avoid double taxation: Both the Article IV and the 14th Amendment Privileges and Immunities Clauses share the animating constitutional principle of national unity and true national citizenship. Retaliatory and protectionist taxing regimes undermine the interest in national unity, and should fall under these clauses.
\end{abstract}

\section{Keywords}

Taxation, Commerce clause, Federalism

\section{Disciplines}

Tax Law 


\section{FLORIDA TAX REVIEW \\ vouUMES}

TAX MY RIDE: TAXING COMMUTERS IN OUR NATIONAL ECONOMY

by

Morgan L. Holcomb

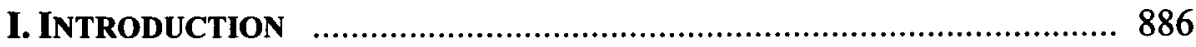

PART I. STATE TAXATION OF INCOME FROM EXPERIMENTAL

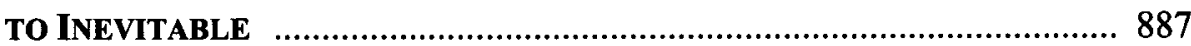

A. Taxation of Individual Income ............................................... 887

B. Apportionment: Taxation of Business Income ......................... 893

C. What's Good Enough for Business Income ought to be Good

Enough for Individual Income .................................................. 895

PART II. CONSTITUTIONAL NORMS - IN THE BEGINNING ....................... 897

A. Dormant Commerce Clause Doctrine and Taxation ............ 897

1. The Founder's Intent: The Historic Purpose of the

Commerce Clause ............................................................. 897

2. The Dormant Commerce Clause and State Taxation:

Complete Auto Transit Test ............................................. 900

3. Application of the Complete Auto Transit Test ........... 902

B. The Privileges and Immunities of Taxation ............................. 903

1. The Privileges and Immunities Clause of Article IV ... 903

2. The Privileges of Immunities Clause of the

14th Amendment ............................................................. 907

Part III. Constitutional NORMS AS COMPLIMENTARY .................... 911

A. The Perils of Double Taxation ............................................... 911

B. Constitutional Norms and Commuting .................................... 919

1. The Interstate Market for Employees .......................... 919

2. Historic Purposes and Modern Commuters ................ 920

3. Constitutional Overlap ................................................ 926

II. ConCLUSION ......................................................................... 929 
TAX MY RIDE: TAXING COMMUTERS IN OUR NATIONAL ECONOMY

\author{
by
}

Morgan L. Holcomb*

\title{
I. INTRODUCTION
}

Located on the scenic St. Croix River, Hudson, Wisconsin is just a half-hour drive from the major metropolitan area of Minneapolis and St. Paul - "the Twin Cities" of Minnesota. Hudson is, therefore, a popular "bedroom" community for Twin Cities' workers. Those commuters, the Wisconsin residents who work in Minnesota, face taxation by two sovereign states: ${ }^{1}$ They are taxed by the state of Wisconsin on the basis of their residency in Wisconsin, and they face taxation by Minnesota on the income that was "sourced" or earned, in Minnesota. ${ }^{2}$

It is well-settled that both states are entitled to tax at least some portion of our Wisconsin commuters' incomes. What is less settled is the

* Visiting Assistant Professor, Hamline University School of Law. This article was written while the author was a Visiting Assistant Professor at the University of Minnesota School of Law. This article benefited from valuable feedback from Mary Patricia Byrn, Mary Louise Fellows, Walter Hellerstein, Kristin Hickman, Joel Michael, Roy Spurbeck, and Edward A. Zelinsky, as well as comments from a University of Minnesota Faculty Workshop. University of Minnesota students in the author's Fall 2007 Tax Policy class provided excellent commentary and challenging questions which improved the article. University of Minnesota School of Law Co-Deans Guy Charles and Fred Morrison provided funding for outstanding research assistant Caroline Rummel. Special thanks to Roy, Ella, and Ruby.

1. A third sovereign to which Wisconsin residents must pay tax is the federal government. This article is concerned with horizontal federalism; this article is not concerned with the propriety of taxation by the federal government and an individual state.

2. This example is illustrative because Minnesota and Wisconsin have a reciprocity agreement under which the states have agreed to refrain from asserting source-based taxation against residents of the other state working within their borders. See Minn. Stat. $§ 290.081$ (2006). The Minnesota-Wisconsin agreement is unusual, and the problem suggested by the hypothetical is not theoretical. In particular, New York, a city with a huge number of teleworkers and commuters, is notorious for its aggressive collection practices. See infra note 169, and accompanying text. 
constitutional limit of the "double" taxation that can occur when two states claim to be the source of income, a situation that is happening with increasing frequency in our increasingly mobile, and telecommuting, population. If, for example, a Wisconsin resident worked for a Minnesota employer, but occasionally worked from home, both Wisconsin and Minnesota could claim to be the source of the income. If both states claim to be the source of the income, the commuter will be taxed twice on that portion of her income, a result that doubtless seems markedly unfair to our commuter. The question this article explores is becoming increasingly pressing. Demographic and work place trends, along with increasingly aggressive state revenue collection practices, ${ }^{3}$ combine to predict that the question of fair apportionment of individual taxation will only grow in importance. ${ }^{4}$

The article begins with a comparison of state taxation of individual and business income. Part II proceeds to explore the relevant constitutional norms: the dormant Commerce Clause and the Privileges and Immunities Clauses of both Article IV and the 14th Amendment. Part III synthesizes these Constitutional norms and their application to commuters. Part IV concludes with a discussion of the growing importance of this question and the avenues for possible resolution.

\section{PaRT I - STATE TAXation OF INCOME - FROM EXPERIMENTAL TO INEVITABLE}

An understanding of the problem faced by interstate commuters begins with an assessment of how state taxation of individual income has developed. Those practices can then be compared to the collection practices of business income. Part I provides that assessment.

\section{A. Taxation of Individual Income}

The personal income tax now seems as American as Mickey Mouse, ${ }^{5}$ and as certain as death, ${ }^{6}$ but this was not always the case. Though several

3. Gerald B. Silverman, Institute Report Says State Tax Revenues Increased by $4.8 \%$ in First Quarter, 120 Daily Tax Rep. (BNA) H-2 (Jun. 22, 2007).

4. This same predicament faces commuters who travel to major work force centers from neighboring states, including, for example, New York City, Washington D.C., and Chicago.

5. Marjorie E. Kornhauser, Robert Stanley, Dimensions of Law in the Service of Order: Origins of the Federal Income Tax, 1861-1913, 44 J. Legal Educ. 288, 288 (1994) (book review) (noting that despite the fact that other countries use the income tax, it "seems characteristically American").

6. Cf. Gary Martin, The Phrase Finder, http://www.phrases.org.uk/meanings/death-and-taxes.html (last visited Aug. 6, 
states experimented with income taxes in 19 th Century, ${ }^{7}$ it was not until the early part of the 20th Century that states imposed income taxes with any regularity. ${ }^{8}$ By the 20 th Century, however, almost every state imposed personal income taxes. ${ }^{9}$ The personal income tax is now a behemoth revenue generator, accounting for about a third of the revenues generated by the states. ${ }^{10}$ The federal income tax grew up roughly parallel with the state income taxation regime. ${ }^{11}$ The federal government collected an income tax during the Civil War, and then again enacted an income tax statute in $1894 .^{12}$ Although the 1894 statute was struck down as a violation of the prohibition on "direct" taxes in Article I, Section 9, clause 4, ${ }^{13}$ the 16 th Amendment permitted Congress in 1913 to enact the precursor to our modern income tax regime. ${ }^{14}$ Initially very few citizens were obliged to pay the income tax, which was imposed only on the extraordinarily wealthy. ${ }^{15}$ It was not until

2007), attributing the quote to various sources. Martin notes that Benjamin Franklin used the familiar form of the phrase, "In this world nothing can be said to be certain, except death and taxes," in a letter to Jean-Baptiste Leroy in 1789. Id.

7. Jerome R. Hellerstein \& Walter Hellerstein, Cases and Materials 928 (8th ed. 2005).

8. Hellerstein \& Hellerstein, supra note 7, at 928-29; see also Susan Pace Hamill, An Argument for Tax Reform Based on Judeo-Christian Ethics, 54 Ala. L. Rev. 1, 112 n.10 (2002) (citing 2 Jerome R. Hellerstein \& Walter Hellerstein, State Taxation I 20.01 (1st ed. 1992)).

9. Hellerstein \& Hellerstein, supra note 7, at 928.

10. Hellerstein \& Hellerstein, supra note 7, at 929 (noting that in the period ending June 2004, state governments collected $\$ 193.2$ billion, or $33.2 \%$ of the total state tax collections).

11. John K. McNulty, Flat Tax, Consumption Tax, Consumption-Type Income Tax Proposals in the United States: A Tax Policy Discussion of Fundamental Tax Reforms, 88 Cal. L. Rev. 2095, 2098 (2000) (noting that "The Federal Income Tax has served this country well for most of the twentieth century, continuously since 1913 (since 1909 for corporate taxpayers), and with roots even earlier than that.")

12. William A. Klein, Joseph Bankman \& Daniel N. Shaviro, Federal Income Taxation 4-6 (14th ed. 2006); see also Marjorie E. Kornhauser, The Origins of Capital Gains Taxation: What's Law Got to Do With It?, 39 SW. L.J. 869, 871-72 (1985) (providing a brief discussion of the history of the federal income tax and noting that "The entire federal income tax system, in fact, was largely experimental.").

13. Pollock v. Farmers' Loan \& Trust Co., 157 U.S. 429, aff'd on reh'g, 158 U.S. 506 (1895).

14. Klein, Bankman, \& Shaviro, supra note 12, at 4-6; McNulty, supra note 12 , at 2098.

15. See Klein, Bankman \& Shaviro, supra note 12, at 4-6 (noting that the exemption of up to $\$ 4,000$ for married couples made the early income tax a tax on the "well-to-do"); Kornhauser, supra note 12, at $873 \mathrm{n} .18$ (noting that in 1920, only approximately $13 \%$ of the labor force paid income taxes). 
World War II and its aftermath that the federal income tax became, as it is today, "a mass tax"16 or perhaps more aptly, a tax on the masses. Most of us, the masses, must file income tax returns to the United States each year. ${ }^{17}$

Most of us also file income tax returns to our home state, that is, our state of residence or domicile. ${ }^{18}$ At least some of us, and an increasing number of us, must also file an additional income tax return, that is to the state or states in which we earn income, if that state is not our state of residence. ${ }^{19} \mathrm{~A}$ state of residence can tax its residents on income those residents earn, regardless of where the income is earned. ${ }^{20}$ Residence-based taxation is premised on the idea that residents of a state have a special relationship to their home state. ${ }^{21}$ As the Court put it, "[e]njoyment of the

16. Klein, Bankman \& Shaviro, supra note 12 , at 5 .

17. In 2005 , just over 52 million returns were jointly filed by married couples, accounting for about 104 million people. Internal Revenue Service, SOI Tax Stats, available at www.irs.gov/pub/irs-soi/05in $12 \mathrm{~ms}$.xls. Approximately 2.4 million married people filed separately. Id. Almost 20 million people filed as head of household, about 71,000 filed as surviving spouses, and just over 59 million people filed as single. Id. Thus a total of approximately 185.5 million people filed tax returns for tax year 2005. Id. In 2005, 56.4 million people in the U.S. were age 13 or younger, and thus most likely too young to work and have a filing requirement. Press Release, U.S. Census Bureau, Nation's Population One-Third Minority (May 10, 2006), available at http://www.census.gov/PressRelease/www/releases/archives/population/006808.html. Assuming that the vast majority of the 185.5 million filers in 2005 were over age 13 , it is possible to estimate that approximately $76 \%$ of people over age 13 filed a 2005 tax.

18. Hellerstein \& Hellerstein, supra note 7 , at 929 (noting that " 41 states and the District of Columbia levy broad-based personal income taxes.")

19. Ferdinand P. Schoettle, State and Local Taxation: The Law and Policy of Multi-Jurisdictional Taxation 521 (2003) (noting that states have "begun developing apportionment rules that apply to a broader base of nonresident individuals" and that states have "increased efforts to collect taxes from nonresident individuals").

20. Oklahoma Tax Comm'n v. Chickasaw Nation, 515 U.S. 450, 462-63 (1995) (noting that it is well established that "a jurisdiction, such as Oklahoma, may tax all the income of its residents, even income earned outside the taxing jurisdiction."); Shaffer v. Carter, 252 U.S. 37, 57 (1920). Although the focus of this article is on state taxation, it is worth noting that the United States taxes the worldwide income of its citizens, a practice that renders the United States "an outlier in the international community." Michael S. Kirsch, Taxing Citizens in a Global Economy, 82 N.Y.U. L. Rev. 443, 445 (2007).

21. It seems intuitively correct that one can be a citizen of only one state at a time. E.g., Sanford Levinson, Suffrage \& Community, 41 Fla. L. Rev. 545, 554 (1989) ("We do not recognize [] dual status; thus, a citizen of Massachusetts cannot legally also be a citizen of Rhode Island (any more than, in the United States, the spouse of A can also be the legal spouse of B."). That intuition, however, has failed to convince the Court that there is any due process violation when two states claim 
privileges of residence in the state and the attendant right to invoke the protection of its laws are inseparable from responsibility for sharing the costs of government." 22

If the special relationship between a resident and her home state justifies the taxation of a resident's income, some other rationale must justify the taxation of nonresidents. Indeed, nonresident taxpayers long challenged the ability of "source states" to tax any nonresident's income. The Court finally laid the question to rest in the seminal case of Shaffer v. Carter ${ }^{23}$ in which the Court firmly rejected the notion that states lacked taxing authority over nonresidents, calling it a "radical contention" that could be "easily answered by reference to fundamental principles." ${ }^{24}$ One such principle is our special brand of federalism, and the concomitant autonomy and sovereignty of the several states that gives them "complete dominion over all persons, property, and business transactions within their borders." ${ }^{25}$ The Court went on to emphasize that states have a duty to preserve and protect all persons, property and business within their borders, and the people, property and businesses within the states' borders have a corresponding duty to remit taxes for those protections. ${ }^{26}$ The Court concluded with strident language, "That the state, from whose laws property and business and industry derive the protection and security without which production and gainful occupation would be impossible, is debarred from exacting a share of those gains in the

authority to tax a decedent's estate as if the decedent were a resident. In Guaranty Trust Co. v. Virginia, New York and Virginia both assessed estate taxes on identical income. The Court rejected a due process challenge to the assessment, holding that "Here, the thing taxed was receipt of income within Virginia by a citizen residing there. The mere fact that another state lawfully taxed funds from which the payments were made did not necessarily destroy Virginia's right to tax something done within her borders." 305 U.S. 19, 23 (1938). See also Douglas Laycock, Equal Citizens of Equal and Territorial States: The Constitutional Foundations of Choice of Law, 92 Colum. L. Rev. 249, 316-17 (1992) ("An American state is not like a nomadic tribe, with membership based on kinship. ... The state . . is defined by its territory, and 'its people' are defined by the territory in which they live."); Lemmon v. People, 20 N.Y. 562, 609 (1860) ("The position that a citizen carries with him, into every state which he may go, the legal institutions of the one in which he was born, cannot be supported."). This question of the persuasiveness of the Court's reasoning in Guaranty Trust will be reserved for another article.

22. New York ex rel. Cohn v. Graves, 300 U.S. 308, 313 (1937). See generally Walter Hellerstein, Some Reflections on the State Taxation of a Nonresident's Personal Income, 72 Mich. L. Rev. 1309 (1974) [hereinafter Hellerstein, Some Reflections] (discussing the basis on which states may permissibly tax both residents and non-residents).

23. Shafer, 252 U.S. at 57.

24. Id. at 50.

25. Id.

26. Id. 
form of income taxes for the support of the government, is a proposition so wholly inconsistent with fundamental principles as to be refuted by its mere statement."27

Despite the Court's firm rejection of the argument that a nonresident source state cannot tax nonresident income, there is no doubt that the nonresident state enjoys a more limited taxing authority than a resident state enjoys over its domiciliaries. Source states may tax only the income that is earned in the source state. ${ }^{28}$ The Schaffer Court noted that a State's jurisdiction to tax nonresidents "extends only to their property owned within the State and their business, trade, or profession carried on therein, and the tax is only on such income as is derived from those sources. ${ }^{\text {29 }}$ Taxpayers have "a more narrowly defined relationship" ${ }^{30}$ with states in which they are not residents, and there is a correspondingly more circumscribed ability of those states to tax. Unlike states of domicile or residence, states in which taxpayers enter for a limited time do not provide the same benefits and protections to taxpayers. ${ }^{31}$ The jurisdiction to tax, therefore, bears some rough relationship to the benefits provided to taxpayers. ${ }^{32}$

That two states are authorized to tax individual income has led to persistent taxpayer indignation about the resulting double-taxation. Historically, this concern has been mitigated by the residency state offering credits for taxes collected by the source state. ${ }^{33}$ To illustrate, assume that a Wisconsin commuters earns the $90 \%$ of her income in Minnesota. Minnesota will tax that income because Minnesota is the source state. ${ }^{34}$ Double taxation

27. Id.

28. Id. at 57. "Source" based taxation is an international norm. Kirsch, supra note 20, at 448-49 (noting that "all countries recognize (and most countries, including the United States, exercise) the right of a country to tax income of a foreign person that arises within the country's borders").

29. Shafer, 252 U.S. at 57.

30. Hellerstein, Some Reflections, supra note 22, at 1318.

31. Id. at 1319.

32. Id.

33. See, e.g., Wis. Stat. $§ 71.07(7)$ (2006); Wisconsin Department of Revenue Schedule OS, Credit for Net Tax Paid to Another State, available at http://www.dor.state.wi.us/forms/2006/06i-023.pdf (explaining that Wisconsin residents who paid tax on the same income to another state in the same tax year qualify to claim the credit). This same practice of residence state deferring to source state is also the norm in international taxation. Kirsch, supra note 21 , at 456 ("The foreign tax credit reflects an acknowledgment that the country in which income arises has the first claim on taxing that income, and that a country exercising residence-based (or citizenship-based) taxation will only collect tax on that foreign income to the extent the source country does not.").

34. Minnesota Department of Revenue, Part-Year Residents and Nonresidents, available at http://www.taxes.state.mn.us/individ/residency_and_filing _status/part_year_non_resident/partyear_residents_non.shtml (last visited Aug. 23, 
is avoided by Wisconsin's decision to give her a credit for the taxes paid in Minnesota. ${ }^{35}$ In other words, Wisconsin will not tax that portion of her income that was already taxed by Minnesota. The remaining $10 \%$ of her income, perhaps income from interest or dividend income, will be taxed by Wisconsin, but not Minnesota.

This solution, however, is imperfect. Most states grant credits only to "source" income taxes paid, and the states have differing definitions of what constitutes source income. ${ }^{36}$ That is, New York taxes an individual on income that New York considers sourced in New York, but Connecticut taxes that same income, contending that the income was in fact sourced in Connecticut. ${ }^{37}$ More fundamentally, the solution is flawed because the credit granted, usually by the State of residence, is seen not as an imperative in a Constitutional or some other sense, but is understood as granted by the grace of the State.$^{38}$ In other words, the credit-granting State at any moment could change its collective mind, and repeal the credit provision.

2007) ("Part-year residents and nonresidents pay tax only on their Minnesota sources of income ....").

35. Wis. Stat. $§ 71.07(7)$ (2006); Wisconsin Department of Revenue Schedule OS, Credit for Net Tax Paid to Another State, available at http://www.dor.state.wi.us/forms/2006/06i-023.pdf; Minn. Stat. $§ 290.081$ (2006). Minnesota residents are required to complete Form M1CR when filing their state income tax returns in order to claim the credit for taxes paid to other states. The Minnesota Department of Revenue web site provides instructions to filers:

The state of Minnesota taxes all of the income of a Minnesota resident, regardless of where it was earned. Occasionally, other states or Canadian provinces may tax this same income if a Minnesota resident temporarily worked ... in the other state. To prevent double taxation of this income, a resident may file Schedule M1CR ... to receive credit for the taxes paid.

Minnesota Department of Revenue, Credit for Taxes Paid to Another State, available at http://www.taxes.state.mn.us/individ/other_supporting_content/taxes_paid\%20 to another state.shtml (last visited Aug. 23, 2007).

36. E.g., Hellerstein \& Hellerstein, supra note 7 (noting that it is generally the credit granting state that "determines the sourcing rules that are used to determine whether the state that is purporting to tax on a source basis is taxing income that has its source in that country for tax credit purposes" which can "result in double taxation").

37. Indeed, this was the exact situation facing law professor Edward Zelinsky when New York and Connecticut both taxed the income he earned as a law professor for Benjamin N. Cardozo School of law. The factual scenario is detailed in the New York Court of Appeals decision reported at Zelinsky v. Tax Appeals Tribunal, 801 N.E.2d 840 (N.Y. 2003) cert. denied 541 U.S. 1009 (2004). For a discussion of the Zelinsky case, see infra notes 204, 210 and corresponding text.

38. "It is well established . . . that the Due Process Clause imposes no restraints on such double taxation (state power to tax based on both residence and source)." Hellerstein \& Hellerstein, supra note 7, at 942. "To deal with the problem 
Returning to the example set out in the introduction: Let us now assume that our commuter and her employer decide that they should capitalize on the ease and benefits of telecommuting, and the employer directs our commuter to work at least two days a week, or $40 \%$ of the time, from home. They hope that this arrangement will serve them both - allowing the employee to avoid commuting stress and be more productive, and enabling the employer to reap the benefits of the increased productivity, retain a valued employee and save on overhead. ${ }^{39}$ Both states now have a legitimate claim to consider the income that the commuter earns while working from home to be sourced to their State. If Minnesota continues to lay claim to the income tax revenues, and Wisconsin does as well, so that so that the commuter pays income tax on approximately $126 \%{ }^{40}$ of her income, is there any constitutional redress?

\section{B. Apportionment: Taxation of Business Income}

Now assume our commuter is not a commuter, but instead, a business headquartered in Wisconsin doing business nationally. If our commuter were such a multistate business, the Constitution would indeed provide protection from multiple taxation. ${ }^{41}$ In particular, the Due Process

of double taxation resulting from the overlapping claims of power to tax on the basis of residence and source, all states with broad-based personal income taxes provide a credit for taxes paid by their residents to other states." Id. This same problem of potential "double" taxation arises in the international context. In international tax "The residence country generally eliminates double taxation by either exempting the item of income from its tax base or by giving a credit against the domestic tax liability for the foreign tax." Hugh J. Ault \& Brian J. Arnold, Comparative Income Taxation: A Structural Analysis 357 (2d ed. 2004).

39. E.g., Nick Paumgarten, There and Back Again, New Yorker, Apr.16, 2007, at 58,64, available at http://www.newyorker.com/reporting/2007/04/16/07041 $6 \mathrm{fa}$ _fact paumgarten (reporting that many studies have shown that "[c]ommuting makes people unhappy ....."). According to Harvard political scientist Robert Putnam, "every ten minutes of commuting results in $10 \%$ fewer social connections" Id. Commuting can also take a physical toll on people. "Researchers have found that hours spent behind the wheel raise blood pressure and cause workers to get sick and stay home more often. Commuters have lower thresholds for frustration at work, suffer more headaches and chest pains, and more often display negative moods at home in the evenings." Eric M. Weiss, Your Car + Your Commute = A Visit to Your Doctor, Wash. Post, Apr. 9, 2007, at B01.

40. Recall that our commuter earns only $90 \%$ of her income from her Minnesota job; if Minnesota continues to tax $90 \%$, and Wisconsin now taxes $40 \%$, she will be taxed on approximately $126 \%$ of her income.

41. Hellerstein \& Hellerstein, supra note 8 , at $192-325,351-426$ (discussing, respectively, Commerce Clause and Due Process Clause restrictions). 
Clause $^{42}$ requires that a state not tax income earned beyond its borders, and the Commerce Clause limits taxes to income that is "fairly apportioned" to the taxing state. ${ }^{43}$ The Constitutional requirement of apportionment will be discussed at length in Part II, but to illustrate, assume the business earns $40 \%$ of its income in Wisconsin and the remaining 60\% in Minnesota. Both states can tax some of the business income, but neither state can $\operatorname{tax} 100 \%$ of the income. $^{44}$ In fact, the states have developed relatively sophisticated apportionment formulas and schemes to tax only the income that can be "reasonably attributed" to that state. ${ }^{45}$

When a company operates in multiple states, it can be quite difficult to decide where income is "earned" and consequently it can be difficult to determine to which state the income can be reasonably attributed. For example, if a Minnesota company manufactures widgets in Minnesota and then sells the widgets nationally, how will the company and the state revenue departments determine the amount of income attributable to each state? Assume the company makes $\$ 100$ profit on the sale of a widget and the sale

42. The Due Process clause also applies to taxation of individual income. An individual must have a nexus with the taxing state for the state to exert its taxing authority. So long as an employee spends a minimal amount of time in the state, due process standards are satisfied. See, e.g., Zelinsky v. Tax Appeals Tribunal, 801 N.E.2d 840, 849 (N.Y. 2003), cert. denied, 541 U.S. 1009 (2004) ("[a] state ... may not tax value earned outside its borders") (citing Allied-Signal, Inc. v. Director, Div. of Taxation, 504 U.S. 768, 777, (1992)).

43. Quill Corp. v. North Dakota, 504 U.S. 298, 306 (1992) ("The Due Process Clause 'requires some definite link, some minimum connection, between a state and the person, property, or transaction it seeks to tax." (quoting Miller Bros. Co. v. Maryland, 347 U.S. 340, 344-45 (1954)); Complete Auto Transit Inc. v. Brady, 430 U.S. 274, 279 (1977) (setting forth a four-prong test that state taxes must pass to be constitutional per the Commerce Clause; the prongs include (1) the taxing state must have a substantial nexus to the tax, (2) the tax must be fairly apportioned to services provided by the taxing state; (3) the tax must not discriminate; and (4) the tax must be fairly related to the services provided by the State).

44. Northwestern States Portland Cement Co. v. Minnesota, 358 U.S. 450 (1959) (holding that both Minnesota and Iowa could tax the income earned by a corporation because, although the corporation was headquartered in Iowa, it made sales in Minnesota as well as Iowa); Complete Auto Transit, 430 U.S. at 279 (the tax must be fairly apportioned to services provided by the taxing state); Moorman Mfg. Co. v. Bair, 437 U.S. 267, 273 (1978) (a state is not required to apportion by identifying geographical source of the corporations profits as long as it's apportionment method provides a "rough approximation of a corporation's income that is reasonably related to the activities conducted within the taxing State.").

45. To be sure, the states are at times aggressive in reconfiguring their apportionment schemes so as to apportion to themselves as much income as possible. See Underwood Typewriter Co. v. Chamberlain, 254 U.S. 113 (1920); Hans Rees' Sons, Inc. v. North Carolina ex rel. Maxwell, 283 U.S. 123 (1931); Butler Bros. v. McColgan, 315 U.S. 501 (1942). 
occurs in Iowa. The near impossible administrative task of determining how much of the profit should be attributed to (and therefore taxable by) Iowa and how much of the profit should be attributable to (and therefore taxable by) Minnesota has led states to settle on apportionment.

Almost all states that impose a corporate income tax use some variation of a three-factor apportionment formula in an attempt to approximate the amount of income attributable to a taxing state. ${ }^{46}$ The factors almost universally include sales, property, and payroll, and the goal is to make a satisfactory, albeit rough, estimate of how income should be divvied up amongst the states. These three factors were chosen because each factor represents an asset commonly understood to contribute to the ability to generate income ${ }^{47}$ Several states have tinkered with the weight given to each factor, a common maneuver is to double-weight the sales factor, ${ }^{48}$ but in broad strokes, there is consensus on how to apportion the income of multistate businesses. Importantly, there is no dispute that apportionment is required.

\section{What's Good Enough for Business Income ought to be Good Enough for Individual Income}

The states have apportioned corporate income for years, but fail to apply those well-settled apportionment rules apply to taxation of individual income. ${ }^{49}$ The resistance to application of the apportionment schemes probably has several bases, but a prime suspect is that because relatively few individuals earn their income in a state that is not their home state, the states have not had to address apportionment. ${ }^{50}$ Even when an individual does cross

46. Hellerstein \& Hellerstein, supra note 7, at 440 (noting that the threefactor test is the most widely used formula).

47. See, e.g., Arthur D. Lynn, Jr., The Uniform Division of Income for Tax Purposes Act Re-Examined, 46 VA. L. Rev. 1257, 1261-62 (1960) ("On the basis of a trial and error process, the so-called Massachusetts formula evolved as the most common general apportionment method. The three factors of sales, payroll, and property were selected as representative income producing elements.").

48. Approximately half of the states imposing a corporate income tax put additional weight on the sales factor, usually double. Hellerstein \& Hellerstein, supra note 7 , at 440 .

49. See Zelinsky v. Tax Appeals Tribunal, 801 N.E.2d 840, 847 (N.Y. 2003), cert. denied, 541 U.S. 1009 (2004) (arguing that "The taxpayer's crossing of state lines to do his work at home simply does not impact upon any interstate market in which residents and nonresidents compete so as to implicate the Commerce Clause," but nonetheless applying the Complete Auto Transit test and finding that even if it did apply to Zelinsky's situation, it would not be violated by New York's convenience of the employer test for allocation of income).

50. More than $73 \%$ (94 million) of all commuters in America work and live in the same county. Alan E. Pisarski, Commuting in America III xv (Transp. 
state lines to work, it historically has been easier to "locate" income earned by an individual than income earned by a multi-state company. If a factory worker commutes from Michigan to Ohio each day to work in the Ford plant, for example, there's not much question that the worker's income is earned in Ohio and is therefore taxable by Ohio. So long as the employee does his or her work in the "source" state, there is relatively little dispute about which state gets to tax the income. The rise of telecommuting, ${ }^{51}$ and the continuing shift in our economy from a goods to a service economy ${ }^{52}$ changes that dynamic. An increasing number of workers structure their employment much like our hypothetical commuter outlined in the introduction - working for an employer in one state from a home in another. In those situations, determining which state, or states, properly lay claim to the income tax revenue becomes a difficult question. ${ }^{53}$ Should the state in which the employer is located tax all of the income? Should the employee's state of

Research Bd. of the Nat'l Acad. 2006), at
http://onlinepubs.trb.org/onlinepubs/nchrp/CIAIII.pdf. This is changing, however, as $51 \%$ of all new workers in the 1990s worked outside of their counties of residence. Id. See also John Leland, Off to Resorts, and Carrying Their Careers, N.Y. Times, Aug. 13, 2007, at A1 (reporting that "location-neutral' migrants" make up a growing percentage of the population of resort towns such as Steamboat Springs, Colorado and Nantucket, among others, and that "[f]rom 2000 to 2006, population in the 297 counties rated highest in natural amenities by the United States Department of Agriculture grew by $7.1 \%, 10$ times the rate for the 1,090 rural counties with below-average amenities").

51. Elizabeth Olson, Executive Life: At Home (Of Course) with a Telecommuter, N.Y. Times, Aug. 24, 2003, at 11 ("Telecommuting has become more popular over the years, and interest spiked after the terrorist attacks of Sept. 11, 2001. According to an estimate from the International Telework Association and Council, which tracks telecommuting, the number of wage eamers who work exclusively from home has increased to roughly 17 million from 5.5 million a decade ago."). Furthermore, the trend is poised to continue. In a 2003 survey by Spherion Corporation, a Fort Lauderdale-based staffing and recruiting company, $96 \%$ of respondents agreed that an employer was more attractive when it helped them meet family obligations through options like flextime, telecommuting, or job sharing. Inst. of Mgmt. and Admin., Inc., Is Your Firm Ready for the Impending War for Talent? Your Employees Are!, 06-3 Law Off. Mgmt. \& Admin. Rep. 2 (Mar. 2006).

52. William J. Holstein, And Now a Syllabus for the Service Economy, N.Y. Times, Dec. 3, 2006, at 10 (noting that the U.S. economy is about $75 \%$ services and stating that universities must prepare students to succeed in a services-based economy).

53. Cf. Robert J. Peroni, Back to the Future: A Path to Progressive Reform of the U.S. International Income Tax Rules, 51 U. Miami L. Rev. 975, 984 (1997) (arguing that international tax policy should move away from source-based taxation given the difficulty of "associating items of income and expense with a particular geographic location"). 
residence tax it all? Or should the states do in individual taxation what they do in the corporate income tax realm - determine some rough way to apportion the income to the state in which it was more properly considered earned?

\section{PART II - CONSTitutional NORMS - IN THE BeginNING}

Two constitutional norms help in the inquiry set out above. The first is the dormant Commerce Clause, and the second is the Privileges and Immunities Clause. This Part will explore the historic purpose of each of these clauses, tracing commonalities among the dormant Commerce Clause and the Privileges and Immunities Clauses. Those commonalities, and their import for telecommuting taxpayers, are then explored in depth in Part III.

\section{A. Dormant Commerce Clause Doctrine and Taxation}

\section{The Founder's Intent: The Historic Purpose of the Commerce Clause}

The dormant Commerce Clause is the notion that even in the absence of Congressional action, the States may not discriminate against or burden the flow of interstate commerce. ${ }^{54}$ Economic protectionism by the states during the time of the Articles of Confederation ${ }^{55}$ was a key concern of the drafters of the Constitution. ${ }^{56}$

54. See Kathleen M. Sullivan \& Gerald Gunther, Constitutional Law 245 (15th ed. 2004).

55. See, e.g., Brannon P. Denning, Confederation-Era Discrimination Against Interstate Commerce and the Legitimacy of the Dormant Commerce Clause Doctrine, $94 \mathrm{Ky}$. L. J. 37, 49 (quoting Cathy Matson, The Revolution, the Constitution, and the New Nation, in 1 The Cambridge Economic History of the United States: The Colonial Era 363, 373 (Stanley L. Eugerman \& Robert E. Gellman, eds., 1996) ("[t]he centrifugal, contentious economic interests rising among the states" at the time "dampened ... postwar enthusiasm and reoriented public and private views toward the Nationalists," who warned that "discrimination against the commerce of neighboring states weakened the economies of all states.")).

56. See H.P. Hood \& Sons, Inc. v. Du Mond, 336 U.S. 525, 534 (1949) ("The necessity of centralized regulation of commerce among the states was so obvious and so fully recognized that the few words of the Commerce Clause were little illuminated by debate."). See also Denning, supra note 55, at 49.

The inability of the Continental Congress to harmonize the commercial policies of the several states, and its failure to convince states to part with that much of their sovereignty as would permit Congress to regulate commerce and raise revenue of its own, convinced many fence-sitters that the problem lay with the Articles of Confederation and encouraged moderate 
State policies, including "[d]ifferent state taxation policies" were of especial concern as those policies "weakened the economies of all states.",57 For example, New York and Massachusetts, states with major ports, "took advantage of their superior position in international commerce and in regional markets to pass discriminatory duties against neighboring states' traffic at their ports, while weaker states tried to divert trade to themselves by abolishing duties altogether, thus setting parameters for intense interstate rivalries by mid-1785.",58

Alexander Hamilton and James Madison addressed the economic protectionism problem in the Federalist Papers. In Federalist No. 7, discussing possible conflicts between the states, Hamilton noted that,

The competitions of commerce would be another fruitful source of contention. The States less favorably circumstanced would be desirous of escaping from the disadvantages of local situation, and of sharing in the advantages of their more fortunate neighbors. Each state, or separate confederacy, would pursue a system of commercial policy peculiar to itself. ${ }^{59}$

Hamilton also foresaw the troubles that would arise in areas where people of neighboring states participated in multi-state markets. For example, New York relied on revenue from laying duties on imports arriving through its ports. New York's practice resulted in residents of New Jersey and Connecticut also paying higher prices for goods, but without the benefit of the duty revenue accumulating in their states' coffers. ${ }^{60}$ Hamilton thus asked, "Would Connecticut and New Jersey long submit to be taxed by New York for her exclusive benefit?"61

James Madison also referenced the detrimental effect of economic competition between the states on the stability of the union.

"We may be assured by past experience, that such a practice [states imposing duties on imports and exports through their

nationalists, like James Madison, that the survival of the Union necessitated substantial changes in the constitutional regime.

57. Cathy Matson, The Revolution, the Constitution, and the New Nation, in 1 Cambridge Economic History of the United States: The Colonial Era 363, 377 (Stanley L. Eugerman \& Robert E. Gellman, eds., 1996). "Merchants in Providence, Rhode Island, believed that they were virtually barred from trade by 1785 because of the high state duties at Massachusetts and New York ports." Id. at 381.

58. Id. at 380 .

59. The Federalist NO. 7 (Alexander Hamilton).

60 . Id.

61. Id. 
borders] would be introduced by future contrivances; and both by that and a common knowledge of human affairs, that it would nourish unceasing animosities, and not improbably terminate in serious interruptions of the public tranquility."

He was concerned not only about the harm to national unity that this would cause, but also the inefficiency of such a practice, noting that "the desire of the commercial States to collect, in any form, an indirect revenue from their uncommercial neighbors, must appear not less impolitic than it is unfair; since it would stimulate the injured party, by resentment as well as interest, to resort to less convenient channels for their foreign trade." ${ }^{63}$

The economic conflict among the states was so alarming to many that it has been cited as "the immediate cause that led to the forming of a [constitutional] convention." ${ }^{64}$ Granting the commerce power to Congress in the Constitution was a means of providing the national government with the power to prevent the states from harming national unity and the national economy through economic protectionism. ${ }^{65}$ The Commerce Clause "embodied a grant of authority to Congress that created the conditions for the free movement of people, transport of products and capital, and uniform institutions that, together, proved crucial to establishing a national market.",66 In the absence of congressional legislation regarding an area of commerce, the Supreme Court enforces the anti-economic protectionism purpose behind the Commerce Clause by striking down state discrimination against interstate commerce through the Dormant Commerce Clause Doctrine. ${ }^{67}$ When analyzing state action that impacts interstate commerce, avoiding "economic Balkanization" has become one of the "central purposes of [the Supreme Court's] negative Commerce Clause jurisprudence." 68

62. The Federalist NO. 42 (James Madison).

63. Id.

64. Camps Newfound/Owatonna, Inc. v. Town of Harrison, 520 U.S. 564, 571 (quoting Gibbons v. Ogden, 22 U.S. 1, 77 (9 Wheat. 1) (1824) (Johnson, J., concurring in judgment)).

65. See Sullivan \& Gunther, supra note 55, at 245 ("The framers of the Constitution centralized the power to regulate interstate commerce in the Congress because they viewed destructive trade wars among the states as a major problem under the Articles of Confederation.").

66. Matson, supra note 57, at 385.

67. See Sullivan \& Gunther, supra note 54, at 245.

68. Camps Newfound/Owatonna, 520 U.S. at 577. 


\section{The Dormant Commerce Clause and State Taxation: Complete Auto Transit Test}

When a business engages in economic activity in more than one state, each of those states will be interested in taxing the business's income. Naturally, the business will want to avoid taxation in the new state if possible, and the home state will want to maintain its tax base. "Conflict between the states' interest in exercising their essential taxing power and the nation's interest in fostering economic unity has been an enduring feature of our federal system." ${ }^{69}$ The Supreme Court noted in Northwestern States Portland Cement Co. v. Minnesota that the issue of state taxation of interstate commerce was so contentious that by 1959 the Court had issued over 300 opinions addressing Commerce Clause challenges to state taxes. ${ }^{70}$

Over time the Supreme Court developed a test to determine whether a state tax violates the dormant Commerce Clause. When a state tax is challenged as violating interstate commerce, the Court applies the four-part Complete Auto Transit test to determine whether the tax rises to an unconstitutional level. ${ }^{71}$ Complete Auto Transit was decided in 1977, wrapping up the Court's journey from holding interstate commerce to be wholly immune to state taxation to allowing interstate commerce to be taxed by any levy that can pass the four-part test. ${ }^{72}$

69. Hellerstein \& Hellerstein, supra note 8, at 192.

70. See id. at 193.

71. Readers familiar with dormant Commerce Clause challenges to non-tax regulatory laws are doubtless familiar with the "Pike balancing test." The Supreme Court does not appear to apply Pike to challenges to state taxes. Though the Supreme Court has not articulated why the Pike balancing test is not applied in state tax discrimination cases, others have noted that the language in Pike refers only to "regulatory" measures (Robert Z. Kelley, Over the Long Haul: State Court Decisions on Flat Truck Taxes, 42 State Tax Notes 103 (Oct. 9, 2006)., quoting Pike v. Bruce Church, 397 U.S. 137 (1970)). The Washington Supreme Court reasoned that regulatory fees fall under the Pike balancing test because fees do not have to be apportioned and do not have to satisfy the internal consistency test. See Franks \& Sons, Inc. v. State, 966 P.2d 1232, 1234-35 (1998), cited in 42 State Tax Notes 103. As taxes do have to meet both of those qualifications (fair apportionment and internal consistency), they must pass the more complex Complete Auto Transit test the Pike balancing test does not do a sufficient analysis to determine the constitutionality of a taxing measure. See id. See also Walter Hellerstein, Is "Internal Consistency" Foolish?: Reflections on an Emerging Commerce Clause Restraint on State Taxation, 87 Mich. L. Rev. 138 (1988) ("Because the distinction between a 'regulatory fee' - subject to the Pike balancing test - and a tax - subject to the Complete Auto four prong analysis - is fuzzy at best, States will likely continue to defend questionable taxes under both theories.").

72. See Hellerstein \& Hellerstein, supra note 7, at 193-205 (summarizing the Supreme Court's changing analysis of state taxation of interstate commerce). 
Before setting forth the 4-part test, it is useful to outline the Court's journey to that point. Initially, the Court reasoned that any tax on interstate commerce constituted a regulation on that commerce, and such regulations were entirely barred due to Congress's power to regulate the privilege of doing interstate business. ${ }^{73}$ This was the "wholly immune" era of the 1870 s. $^{74}$ By the 1930s, the Court had progressed to holding that interstate commerce can be made to "pay its way," but would still strike down any tax which had even a possibility of imposing a multiple tax burden on the taxpayer. ${ }^{75}$ After allowing states to begin taxing the income of interstate businesses, the Court had trouble reaching a clear standard to determine whether states were requiring businesses to do more than just pay their way. The Court's reasoning reached a point where it elevated form over substance, disallowing taxes that were directly imposed on interstate business, but not on indirectly imposed taxes. $^{76}$

After three decades of cases in which the outcome often turned on the label the state gave the tax, ${ }^{77}$ the Court articulated its four-factor test in Complete Auto Transit to determine whether a state's tax on corporate income imposes an impermissible burden on interstate commerce. ${ }^{78}$ The four factors considered are

(1) Nexus: the tax must be applied to an activity that has a substantial nexus with the state;

(2) Apportionment: the tax must be fairly apportioned to activities carried on by the taxpayer in the state;

(3) Discrimination: the tax must not discriminate against interstate commerce; and

(4) Fairly related: the tax must be fairly related to services provided by the state. $^{79}$

73. See The Case of the State Freight Tax, 82 U.S. (15 Wall.) 232 (1872); Hellerstein \& Hellerstein, supra note 7, at 193-98.

74. See The Case of the State Freight Tax, 82 U.S. (15 Wall.) 232 (1872); Hellerstein \& Hellerstein, supra note 7, at 193-98.

75. See Western Live Stock v. Bureau of Revenue, 303 U.S. 250, 254 (1938); Hellerstein \& Hellerstein, supra note 7, at 198-201.

76. See Spector Motor Service, Inc. v. O’Connor, 340 U.S. 602 (1951); Hellerstein \& Hellerstein, supra note 7, at 201.

77. After the Spector Motor Service decision in 1951, many states changed the name of their corporate income taxes from "franchise taxes on the privilege of doing business" to "direct net income taxes." Hellerstein \& Hellerstein, supra note 8, at 202. This practice did not end until 1977 when the Complete Auto Transit decision overruled Spector and "explicitly rejected the formalistic Commerce Clause doctrine that provided the foundation for the Spector rule." Id. at 204.

78. Complete Auto Transit, Inc. v. Brady, 430 U.S. 274, 279 (1977).

79. Id. at 279. 
Each state in which the taxpayer does business has an interest in taxing some of the taxpayer's income, but only to the extent that the taxpayer receives benefits from the state. ${ }^{80}$ The Court's test recognizes that when a taxpayer does business in more than one state, a perfect outcome would be for the taxing states to apportion the income such that the taxpayer would be subject to tax on $100 \%$ of its income, no more and no less. This way interstate business taxpayers are treated the same way as businesses operating in only one state - they are both taxable on all of their income, but no more than that.

\section{Application of the Complete Auto Transit Test}

A state seeking to impose an income tax on a business engaged in interstate commerce may tax only an apportioned amount of the business's income; the apportionment scheme must be intended to reflect the business activity conducted in the state. ${ }^{81}$ This apportionment requirement is a critical prong of the Complete Auto Transit test. When apportioning corporate income, the most commonly used method is the so-called "Massachusetts formula," which includes the three factors of property, payroll, and sales. ${ }^{82}$ States can and do choose other methods of apportionment, such as the singlefactor sales test and a three-factor test with a double-weighted sales factor. ${ }^{83}$ When analyzing a state apportionment formula, the Court considers whether the formula shows "internal consistency." 84

Internal consistency is preserved when the imposition of a tax identical to the one in question by every other State

80. See Quill Corp. v. North Dakota, 504 U.S. 298, 306 (1992), quoting Moorman Mfg. Co. v. Bair, 437 U.S. 267 (1978) (noting that Due Process requires that the income the state seeks to tax have a rational relation to "values connected with the taxing State" and that such a relation could be established by a showing that the state provides protection and services to the taxpayer's local activities).

81. See Hans Rees' Sons v. North Carolina ex rel. Maxwell, 283 U.S. 123, 133 (1931).

82. See, e.g., Lynn, supra note 47 , at 1261-62 ("On the basis of a trial and error process, the so-called Massachusetts formula evolved as the most common general apportionment method. The three factors of sales, payroll, and property were selected as representative income producing elements.").

83. Institute on Taxation and Economic Policy, Corporate Apportionment and the "Single Sales Factor," Policy Brief \#11 (2005), available at http://www.itepnet.org/pbl lssf.pdf.

84. See Armco, Inc. v. Hardesty, 467 U.S. 638 (1984); Tyler Pipe Indus., 483 U.S. 232 (1987); Am. Trucking Ass'ns, 483 U.S. 266 (1987); Okla. Tax Comm'n v. Jefferson Lines, 514 U.S. 175, 184 (1995) (noting that the "principle of fair share is the lineal descendant of [the] prohibition on multiple taxation."). 
would add no burden to interstate commerce that intrastate commerce would not also bear. . . . A failure of internal consistency shows as a matter of law that a State is attempting to take more than its fair share of taxes from the interstate transaction. ${ }^{85}$

It is possible for two states to have apportionment formulas which conflict, resulting in double taxation, but which are both internally consistent.

The Court also asks whether a tax is "externally consistent." That is, the tax must be "fairly attributable to economic activity within the taxing state." ${ }^{86}$ Unlike the tidy thought experiment required by the internal consistency test, external consistency looks to "the economic justification for the State's claim upon the value taxed" with the goal of discovering "whether a State's tax reaches beyond that portion of value that is fairly attributable to economic activity within the taxing State." ${ }^{97}$ The external consistency test is therefore a practical check on taxes that could pass the internal consistency test, but would nonetheless impermissibly burden commerce.

\section{$B$. The Privileges and Immunities of Taxation}

\section{The Privileges and Immunities Clause of Article IV}

Like the dormant Commerce Clause, the Privileges and Immunities Clause of Article IV of the Constitution ${ }^{88}$ prohibits states from discriminating against non-residents. ${ }^{89}$ And like the goal of national unity underlying the

85. Jefferson Lines, 514 U.S. at 185. See also Gen. Motors Corp. v. Tracy, 519 U.S. 278,299 n. 12 (1997) ("the requirement of apportionment ... assur[es] that interstate activities are not unjustly burdened by multistate taxation")

86. Jefferson Lines, 514 U.S. at 185 (citing Goldberg v. Sweet, 488 U.S. $252,262(1989))$.

87. Id.

88. The Article Four Privileges and Immunities Clause is referred to as the "interstate" Privileges and Immunities Clause. It provides that "[t]he Citizens of each State shall be entitled to all Privileges and Immunities of Citizens in the several States." U.S. Const., art. IV, $\$ 2$.

89. Lunding v. N.Y. Tax Appeals Tribunal, 522 U.S. 287, 290-91 (1998) (concluding that "because New York has not adequately justified the discriminatory treatment of nonresidents . . . the challenged [tax] provision violates the Privileges and Immunities Clause."). Although the Privileges and Immunities Clause speaks of discrimination against "Citizens" the Court held that "a general taxing scheme . . . if it discriminates against all non-residents has the necessary effect of including in the discrimination those who are citizens of other states." Travis v. Yale \& Towne Mfg. Co., 252 U.S. 60, 79 (1920). See also Susan M. Cordaro Note, A High Water Mark: The Article IV, Section 2, Privileges and Immunities Clause and Nonresident Beach 
Commerce Clause, a goal motivating this additional anti-discrimination provision was "to help fuse into one Nation a collection of independent, sovereign States." ${ }^{.90}$ Although the Clause arguably has multiple purposes, it is "first and foremost a national unity provision, eliminating a source of interstate divisiveness." 91

As expressed by Chief Justice Taney, the Clause seeks to ensure the avoidance of "discord and mutual irritation" among the states. ${ }^{92}$ Taxes especially taxes one State attempts to export to another State's residents historically have been, and continue to be, a prime area for states to provoke each other to such discord and irritation. ${ }^{93}$ This practice of filling the state

Access Restrictions, 71 Fordham L. Rev. 2525, 2563 n. 21 (2003) ("The Supreme Court has come to view 'citizen' and 'resident' as terms that are 'essentially interchangeable' as part of Article IV, $\S 2$, Privileges and Immunities analysis.") (quoting Hicklin v. Orbeck, 437 U.S. 518, 524 n.8 (1978) (quoting Austin v. New Hampshire, 420 U.S. 656,662 n.8 (1975)))).

90. Toomer v. Witsell, 334 U.S. 385, 395 (1948). See also Hicklin v. Orbeck, 437 U.S. at 523 (noting that the Privileges and Immunities Clause "establishes a norm of comity that is to prevail among the States with respect to their treatment of each other's residents.") (citation omitted); Laycock, supra note 22, at 270 ("The specific concerns that underlie the Privileges and Immunities Clause inform the more general right of equality in the Equal Protection Clause and the equality component of the Commerce Clause.").

91. Laycock, supra note 21 , at 263 (further citing Alexander Hamilton's statement that the Clause was "the basis of the Union.") (citing The Federalist NO. 80, at 478 (Alexander Hamilton) (Clinton Rossiter ed., 1961)).

92. Smith v. Turner (Passenger Cases), 48 U.S. (7 How.) 283, (1849) (Taney, C.J., dissenting) (" [a] tax imposed by a State for entering its territories or harbours is inconsistent with the rights which belong to the citizens of other States as members of the Union, and with the objects which that Union was intended to attain. Such a power in the States could produce nothing but discord and mutual irritation, and they very clearly do not possess it.")

93. The Federalist NO. 7 (Alexander Hamilton); Austin v. New Hampshire, 420 U.S. 656, 662 (1975); see also The Capital-Journal Editorial Board, Border Dispute A Tax War, Topeka CJOnline, at www.cjonline.com/stories/082507op1

194425567.shtml, (last visited Oct. 2, 2007 ) (reporting that Kansas and Missouri are involved in "another border skirmish" over tax treatment of nonresident commuters and foreshadowing a "never-ending battle between state legislatures"); Rick VanderKnyff, MSN Money, Could You Be Hit by the "Jock Tax"?, available at http://moneycentral.msn.com/content/Taxes/P112872.asp (last visited Oct. 2, 2007) (noting that the source-based income taxes states impose on professional athletes arose when California retaliated for the Chicago Bulls' defeat of the L.A. Lakers in the 1991 NBA Finals; other states quickly followed suit in imposing their own "jock taxes"). 
fisc by imposing taxes on outsiders is known as tax exporting. ${ }^{94}$ In an early case, the Court addressed States' attempts to ease the tax burden on their own residents by imposing entry taxes on non-residents. ${ }^{95}$ The majority struck down the tax as violating the Commerce Clause. ${ }^{96}$ Chief Justice Taney, in dissent, set forth his opinion that no State may impose a tax for entering its "territories or harbours" because such a tax "is inconsistent with the rights which belong to the citizens of other States as members of the Union, and with the objects which that Union was intended to attain. ${ }^{997}$ In other words, such a tax violates the Privileges and Immunities Clause as well as the Commerce Clause. Although the Chief Justice was in dissent, his opinion "set the groundwork for a right to travel."

As the Court more recently put it, the Privileges and Immunities Clause "places citizens of each State upon same footing with citizens of other states, so far as the advantages resulting from citizenship in those States are concerned." 99 One such advantage of citizenship is "the right of a citizen of any State to remove to and carry on business in another [State] without being subjected in property or person to taxes more onerous than the citizens of the later State are subjected to." 100 The Court recognizes that taxing authority is fundamental to state sovereignty and as such the Court has noted that its "review of tax classifications has generally been concomitantly narrow." 101 However, when state tax authority pushes up against "an activity granted special constitutional recognition" that deference to state taxing authority yields so that the Court may "protect the competing constitutional value." 102

94. Daniel Shaviro, An Economic \& Political Look at Federalism in Taxation, 90 Mich. L. Rev. 895, 908 (1992) (defining tax exportation as occurring "when governments succeed in placing tax burdens on outsiders."); see also Hellerstein, Some Reflections, supra note 22, at 1333 (striving to find the "constitutional line [that] must be drawn in a manner that allows the state to exercise its taxing power freely but not so freely that it is allowed to care for its own at the expense of others.")

95. The Passenger Cases, 48 U.S. (7 How.) 283 (1849).

96. Id. at 409-410, see also Michelle L. Himes, Note, Constitutional Law You Can't Take it With You: The Constitutionality of Workers' Compensation Rules Based on Residency, 27 W. New Eng. L. Rev. 261, 277-78 (2005). dissenting).

97. The Passenger Cases, 48 U.S. (7 How.) 283, 492 (Taney, C.J.,

98. Patrick M. Garry, The Constitutional Lynchpin of Liberty in an Age of New Federalism Replacing Substantive Due Process with the Right to Travel, 45 Brand. L. J. 469, 494 n. 91 (2007).

99. Lunding v. N.Y. Tax Appeals Tribunal, 522 U.S. 287, 296 (1998)

(quoting Paul v. Virginia, 75 U.S. 168, (8 Wall), 168, 180 (1869)).

100. Id.

101. Austin v. New Hampshire, 420 U.S. 656, 662 (1975).

102. Id. 
Despite its anti-discrimination promise, the Article IV Privileges and Immunities Clause does not bar all disparate treatment of citizens and noncitizens. ${ }^{103}$ In particular, the Privileges and Immunities Clause does not bar all disparate taxation treatment of citizens and non-citizens. ${ }^{104}$ "[I]nequalities that result not from hostile discrimination, but occasionally and incidentally in the application of a [tax] system that is not arbitrary in its classification, are not sufficient to defeat the law."105 If a non-resident demonstrates a taxing scheme results in something less than "substantial equality of treatment"106 for resident and nonresident taxpayers, it is up to the State to articulate a "reasonable ground" for the difference. ${ }^{107}$ States may defend challenged actions by demonstrating a substantial reason for the difference, and showing that the discrimination bears a substantial relationship to the State's objective. ${ }^{108}$

With relative frequency, the high court has held that a state has not sufficiently articulated a reasonable ground for the different treatment of non-residents, and has held a particular tax or fee violates the Article IV Privileges and Immunities Clause. ${ }^{109}$ In a paradigmatic case, Toomer $v$.

103. See Lunding, 522 U.S. at 298 ("The Privileges and Immunities Clause bars 'discrimination against citizens of other States where there is no substantial reason for the discrimination beyond the mere fact that they are citizens of other States. But it does not preclude disparity of treatment in the many situations where there are perfectly valid independent reasons for it."') (quoting Toomer v. Witsell, 334 U.S. 385,396$)$ ). Note that in this way, the Clause differs from the Dormant Commerce Clause; under current Supreme Court doctrine, any tax that discriminates against interstate commerce is per se invalid. But see Laycock, supra note 22, at 259 (arguing that the "Court should be reluctant to imply exceptions to any of these [the Privileges and Immunities Clause, the Equal Protection Clause, and the Commerce Clause] protections.")

104. Lunding, 522 U.S. at 297 ("the Privileges and Immunities Clause affords no assurance of precise equality in taxation between residents and nonresidents of a particular State.").

105. Id. at 297 (quoting Maxwell v. Bugbee, 250 U.S. 525, 543 (1919)). (alteration in original).

106. Id. at 297 (quoting Austin v. New Hampshire, 420 U.S. 656, 665 (1975)).

107. Id. at 298 (quoting Travis v. Yale \& Towne Mfg. Co., 252 U.S. 60, 79

108. Id. For a succinct and accessible description of modern doctrine, Brannon P. Denning, Why The Privileges \& Immunities Clause of Article IV Cannot Replace the Dormant Commerce Clause Doctrine, 88 Minn. L. Rev. 384, 388-93 (2003).

109. See Walter Hellerstein, State Taxation: Third Edition, Part IV, T 20.06[1] "Discrimination Against Non-Residents Under Privileges and Immunities Clause" (1998) (discussing Toomer v. Witsell, 334 U.S. 385 (1948)); Hellerstein \& Hellerstein, supra note 7 , at 86-89 (discussing Toomer, 334 U.S. 385, Mullaney v. 
Witsell ${ }^{110}$ the Court invalidated South Carolina's shrimping license fee that charged non-residents one-hundred times more than South Carolina residents for the privilege of shrimping in South Carolina's coastal waters. ${ }^{11}$ The license fee cases demonstrate clear examples of prohibited state action. They also illustrate, however, a critical limitation on the scope of the interstate Privileges and Immunities Clause. That limit is that only certain "fundamental" rights - those rights "bearing upon the vitality of the Nation as a single entity" are protected. ${ }^{112}$ The Court has consistently held that pursuit of a common calling is a fundamental right. ${ }^{113}$

\section{The Privileges or Immunities Clause of the 14th Amendment}

While the Court has discussed the interstate, or Article IV, Privileges and Immunities Clause in numerous tax cases, the Privileges or Immunities Clause of the 14th Amendment has not figured prominently in tax cases. ${ }^{114}$

Anderson, 342 U.S. 415 (1952), Lunding v. New York Tax Appeals Tribunal, 522 U.S. 287 (1998), Austin v. New Hampshire, 420 U.S. 656 (1975)).

110. 334 U.S. 385. See also Ward v. Maryland, 79 U.S. (12 Wall.) 418, 430 (1871) (striking down a state law that, among other things, charged nonresidents a higher license fee than those in-state residents who were required to secure licenses).

111. Toomer, 334 U.S. at 385 (the statute charged resident-owned boats $\$ 25$ for a license to shrimp, while charging non-resident owned boats $\$ 2,500$ ).

112. Baldwin v. Fish \& Game Comm'n of Montana, 436 U.S. 371, 383 (1978). The understanding of what rights are "fundamental" is undeveloped, at best, as is discussed infra.

113. E.g., United Bldg. \& Constr. Trades Council v. Camden, 465 U.S. 208, 219 (1984) ("Certainly, the pursuit of a common calling is one of the most fundamental of those privileges protected by the Clause."). While shrimping for a livelihood qualifies as a "fundamental" privilege or immunity, hunting big game for sport does not. The high court made this latter point express when it upheld Montana's licensing scheme that charged resident elk-hunters significantly lower fees than non-resident elk-hunters. Baldwin v. Montana Fish \& Game Comm'n, 436 U.S. 371 (1978). See Gillian E. Metzger, Congress, Article IV, and Interstate Relations, 120 Harv. L. Rev. 1468, 1504 (2007) (questioning why national unity is less threatened by discrimination surrounding recreation than commercial activities; noting that the distinction between the shrimp and elk cases "reveals the commercial flavor of the Court's view of the Privileges and Immunities Clause, it leaves unexplained why resentment and retaliation outside the commercial context is less threatening to the nation's well-being.").

114. Indeed, the 14th Amendment Privileges or Immunities Clause has not figured prominently in any subject of the Court's jurisprudence. William J. Rich, Taking "Privileges or Immunities" Seriously: A Call to Expand the Constitutional Canon, 87 Minn. L. Rev. 153, 207 (2002) (lamenting that "The current generation of lawyers and judges has been trained to ignore the Privileges or Immunities Clause."). 
This later Privileges or Immunities Clause instructs that "No State shall make or enforce any law which shall abridge the privileges or immunities of citizens of the United States."115 For over 100 years, the Privileges or Immunities clause of the 14th Amendment was "all but read ... out of the Constitution" by the Slaughter-House Cases. ${ }^{116}$ In 1999, however, the Court reinvigorated the Clause, holding that the clause protects the right to travel. ${ }^{117}$ In particular, the Court held that the 14th Amendment prohibits States from impeding "the free interstate passage of citizens"118 and held that California's cap on welfare benefits for newly arrived residents violated the Privileges and Immunities of the State's new residents. ${ }^{119}$

Like the interstate Privileges and Immunities Clause of Article IV, the 14th Amendment Privileges or Immunities clause, as the Saenz Court noted, protects only "fundamental" rights. ${ }^{120}$ Though the precise definition of what constitutes a fundamental right is unclear, ${ }^{121}$ it seems certain that two

115. U.S. Const. amend. XIV. Although the Amendment refers to "citizens" the Amendment protects residents as well. Rich, supra note 115, at 195 (quoting D.O. McGovney, Privileges or Immunities Clause, 14th Amendment, 4 Iowa L. Bull. 219, 240-41 (1918) ("privileges or immunities of a United States citizen include rights conferred upon him by national law, whether it is conferred upon him because he is a citizen, or because he is a human being. .. [I]t is none the less a privilege of citizens of the United States' that others have the same privilege.")

116. Saenz v. Roe, 526 U.S. 489, 521 (1999) (Thomas, J. dissenting) (noting that "Unlike the Equal Protection and Due Process Clauses . . . the Court all but read the Privileges or Immunities Clause out of the Constitution in the SlaughterHouse Cases."). The Court has not completely ignored the Clause, however. E.g., Colgate v. Harvey, 296 U.S. 404, 431, 433 (1935) ("One purpose and effect of the privileges and immunities clause of the 14th Amendment ... was to bridge the gap left by [Article IV, Section 2] so as also to safeguard citizens of the United States against any legislation of their own states having the effect of denying equality of treatment in respect of the exercise of their privileges of national citizenship in other states .... When [a citizen] trades, buys, or sells, contracts or negotiates across the state line, when he loans money or takes out insurance in New Hampshire, whether in doing so he remains in Vermont or not, he exercises rights of national citizenship which the law of neither state can abridge. ...")

117. According to then Chief Justice Rehnquist, the Saenz case "breathe[d] new life into the previously dormant Privileges and Immunities Clause of the 14th Amendment." Saenz, 526 U.S. at 511 (Rehnquist, C.J., dissenting). The Court's revitalization reinvigorated academic interest. See Scott Dodson, Vectoral Federalism, 20 GA. ST. U. L. Rev. 393, 457 (2003) (noting that "the Privileges or Immunities Clause is experiencing academic revival").

118. Saenz, 526 U.S. at 511-12 (1999) (Rehnquist, J. dissenting).

119. Id.

120. Id.

121. Metzger, supra note 113 , at 1504 (stating "The Court's efforts to render this standard [the 'fundamental' right standard] operational again have not been models of consistency."). 
such rights relevant here include the right to commute; or as it was phrased in the early 19th Century in a discussion of the IV Amendment, the "right of a citizen of one state to pass through, or to reside in any other state, for purposes of trade, agriculture, professional pursuits, or otherwise ..."122 and the right to be free of discriminatory taxation, or, again, as phrased in the landmark ${ }^{123}$ Corfield opinion, "an exemption from higher taxes or impositions than are paid by the other citizens of the state. ..."

Combined, these rights have been explicitly recognized by the Court at least twice: first, in Ward v. Maryland, ${ }^{125}$ and then again in Hicklin v. Orbeck. ${ }^{126}$ The Hicklin Court summarized the protection afforded by the clause: "a resident of one State is constitutionally entitled to travel to another State for purposes of employment free from discriminatory restrictions in favor of state residents imposed by the other State." ${ }^{\prime 27}$ This right to work in another state is the second of three components of the right to travel that the Saenz court articulated. ${ }^{128}$

The shared goal of national unity that underpins both the Commerce Clause and the Article IV Privileges and Immunities Clause is also an aim

122. Corfield v. Coryell, 6 F. Cas. 546 (C.C.E.D. Pa. 1823) (No. 3230). Similarly, the Saenz majority defined as "fundamental" the right to travel. Reference to Corfield to define the privileges and immunities to which the 14th Amendment applies is sound: "The meaning of the terms 'privileges' and 'immunities' did not change when they were repeated in the 14th Amendment." Rich, supra note 115, at 215. See also Michael P. O'Connor, Time Out of Mind: Our Collective Amnesia About the History of the Privileges or Immunities Clause, 93 KY. L. J. 659, 701-02 (2005) (noting that the most obvious place to begin understanding the meaning of "privileges or immunities" in the 14th Amendment is by reference to the "nineteenth-century understanding of the original privileges and immunities clause") (citing Corfield v. Coryell, 6 F. Cas. 546 (C.C.E.D. Pa. 1823) (No. 3,230)).

123. Saenz, 526 U.S. at 524 (Thomas, J. dissenting) (referring to Corfield v. Coryell as "Justice Bushron Washington's landmark opinion.")

124. Corfield v. Coryell, 6 F. Cas. 546, 552 (C.C.E.D. Pa. 1823) (No. 3230). See also Tracy A. Kaye, Tax Discrimination: A Comparative Analysis of U.S. \& EU Approaches, 7 Fla. Tax Rev. 47, 82 (2005) (noting that "the freedom from discriminatory taxation had previously been named as a fundamental right.") (citing Gary J. Simson, Discrimination Against Non-residents and the Privileges and Immunities Clause of Article IV, 128 U. PA. L. Rev. 379 (1979) (citing Corfield v. Coryell, 6 F. Cas. 546, 551 (C.C.E.D. Pa. 1823) (No. 3230))).

125. 79 U.S. 418 (12 Wall.) (1870).

126. 437 U.S. 518 (1978).

127. Hicklin, 437 U.S. at 525 (citing Ward v. Maryland 79 U.S. 418 (12 Well.) (1870)).

128. Saenz, 526 U.S. at 500 , the first component is the right of a citizen of one state to enter and leave another, and the final component is the right to be treated like other citizens once one elects to become a resident of that state. Id. 
animating the 14th Amendment Privileges or Immunities Clause. ${ }^{129}$ Indeed, recent scholarly effort addressing and valuing the 14th Amendment Privileges or Immunities Clause emphasizes the critical national building component of the Clause. ${ }^{130}$

William J. Rich, for example, undertakes a careful examination of the historic context of the 14th Amendment, and persuasively concludes that the 14th Amendment changed [the] federal balance and "strengthened the values of nationhood, equality, and democracy."131 Professor Rich emphasizes the "central importance of national citizenship and democratic control" to the Amendment. ${ }^{132}$ Rich notes the majority opinion for the Slaughterhouse cases identified four sources of federal privileges or immunities: negative constraints in the text of the Constitution; rights derived from the "national character" of the government; ${ }^{133}$ "federal privileges or immunities incorporated [into] the "right to peaceably assemble and petition for redress of grievances;",134 and finally, the "right to use the navigable waters of the United States." 135 As Rich points out, this last category is "fundamental" and reflects that the "right to use navigable waters referred to the Commerce Clause."136 This constitutional overlap that Rich identifies - the right to use navigable waters that is present in both the understanding of federal privileges or immunities and explicitly in the Commerce Clause - illustrates the critical role this interest plays in our Union.

129. Jide Nzelibe, Free Movement: A Federalist Reinterpretation, 49 AM. U. L. Rev. 433, 435 (1999) (attempting "to dispel the notion that the limitation on a state's power to restrict interstate travel and migration is based upon a notion of a personal right to travel" ... and instead positing that "this limitation, like the dormant Commerce Clause, is traceable to an idea of conserving the political and economic union against provincial state interests.") (citation omitted).

130. E.g., Rich, supra note 114; James W. Fox, Jr., Democratic Citizenship \& Congressional Reconstruction: Defining \& Implementing the Privileges \& Immunities of Citizenship, 13 Temp. Pol. \& Civ. Rts. L. Rev. 453 (2004) (considering the "implementation of the 14th Amendment during Reconstruction through the lens of democratic citizenship"); Thurgood Marshall, Reflections on the Bicentennial of the United States Constitution, 101 Harv. L. Rev. 1, 4 (1987) ("While the Union survived the Civil War, the Constitution did not. In its place arose a new, more promising basis for justice and equality, the 14th Amendment.")

131. Rich, supra note 114, at 158.

132. Id.

133. Id. (citing The Slaughter-House Cases, 83 U.S. 36, 79 (1873)).

134. Id. at 181-82 (quoting Slaughter-House Cases, 83 U.S. 36, 79 (1873)).

135. Id. at 181-82, (quoting Slaughter-House Cases, 83 U.S. 36, 79 (1873)).

136. Id. at 182 . 


\section{PART III - CONSTITUTIONAL NORMS AS COMPLEMENTARY}

Part III begins with an exploration of the perils of double taxation, and proceeds to demonstrate that the dormant Commerce Clause, which is said to protect "markets and market participants, not taxpayers as such"137 does in fact protect the "market" for employees, and therefore should provide solace to interstate commuters and teleworkers. This Part also synthesizes the goals of the Privileges and Immunities Clause with those of the dormant Commerce Clause, and demonstrates that the Privileges and Immunities Clause does not occupy the field to the exclusion of the dormant Commerce Clause. Even if the dormant Commerce Clause did not apply to interstate commuters, both the 14th Amendment Privileges and Immunities Clause and the dormant Commerce Clause were, and continue to be, concerned with national unity and true national citizenship. Retaliatory and protectionist taxing regimes undermine the interest in national unity, and therefore are constitutionally prohibited.

\section{A. The Perils of Double Taxation}

Double taxation doubtless seems unfair to an individual taxpayer, but its impact on the overall economy is even more pernicious. Fairness in itself is a basic building block of a good taxing system. ${ }^{138}$ Fairness is admittedly a hazy concept, but for the purposes of this article, a straightforward characterization borrowed from scholar Linda Beale will suffice: a fair tax system is one in which "taxpayers . . . believe that they will not be required to pay too much tax in comparison to other taxpayers." 139 Fairness is important for its own sake, but fairness and the perception of fairness are also critical when tax systems rely significantly on voluntary

137. General Motors Corp. v. Tracy, 519 U.S. 278, 300 (1997).

138. E.g., Linda M. Beale, Book-Tax Conformity \& the Corporate Tax Shelter Debate: Assessing the Proposed Section 475 Mark-to-Market Safe Harbor, $24 \mathrm{Va}$. Tax Rev. 301, 359 (2004) (stating that "As any introductory tax text makes clear, the three concerns traditionally considered determinative of tax policy are fairness, efficiency, and simplicity.")

139. Id. at 371. See also Stephen J. Dubner \& Steven D. Levitt, Filling in the Tax Gap, N.Y. Times Magazine, Apr. 2, 2006, at 26 (setting forth evidence that the average (federal income) taxpayer underpays by about one-fifth, and arguing that "unless you are personally cheating by one-fifth or more, you should be mad at the I.R.S. - not because it's too vigilant, but because it's not nearly vigilant enough. Why should you pay your fair share when the agency lets a few hundred billion dollars of other people's money go uncollected every year?"). 
compliance, as ours do. ${ }^{140}$ Compliance is more likely when taxpayers believe that the system is fair. ${ }^{141}$

To the extent that a taxing system requires interstate commuters to pay more than similarly situated intra-state commuters, the double-taxation is perceived to be, and is, unfair. This perception of unfairness chips away at the taxpaying public's faith in the tax system. This is a serious critique given the current "tax gap."142

The fairness problem is illustrated by analogy to the taxation faced by professional athletes. After the Chicago Bulls defeated the L.A. Lakers in the 1991 NBA Finals, California got even by enacting the first "jock tax."143 When a professional athlete plays an away game, the city and/or state where the game is played will tax the athlete's income earned that day, claiming it is sourced in that jurisdiction. ${ }^{144}$ The tax is most commonly calculated using a ratio of "duty days," where the number of days the athlete is required to be in the taxing city/state for team duties is divided by the total number of days in the year the athlete is required to perform team duties. ${ }^{145}$

While many of these taxes apply to all people entering a state to work and earn income, professional athletes and entertainers are the most common targets of this tax because their schedules are public and announced in advance, giving tax administrators easy access to the information they need to assess the tax. ${ }^{146}$ The targeting of athletes based on their high salaries

140. E.g., Id. (noting that "most people aren't cheating" on their federal income taxes, and reporting that experts estimate "that the U.S. is easily within the upper tier of worldwide compliance rates").

141. Beale, supra note 138 , at 371 .

142. E.g., Dubner \& Levitt, supra note 139, at 26 (discussing in general terms the federal income tax "tax gap"). The "tax gap" is not a uniquely American problem. See Eric J. Lyman, Vatican Officials Say Papal Encyclical Will Condemn Tax Evasion, Tax Havens, BNA Daily Tax Report, No. 158, Aug. 16, 2007 at I-1 (reporting that Pope Benedict XVI has equated tax evasion to stealing and will release "an encyclical that will condemn tax evasion as 'socially unjust;" and further reporting that "statements from the Vatican ... can have an impact on the behavior of individuals or companies and on policy in poor and predominantly Catholic countries in Latin American, Africa, and parts of Asia.").

143. Rick VanderKnyff, Could You Be Hit by the Jock Tax?, MSN Money, http://moneycentral.msn.com/content/Taxes/P112872.asp (last visited Aug. 7, 2007). As of 2006, 20 states had enacted a jock tax. Mike Baker, State Lawmaker Proposes "Retaliation" Tax on Athletes, Seattle Post-Intelligencer, Feb. 6, 2006, available at http://seattlepi.nwsource.com/local/258384_gjock06.html.

144. See Thomas Heath and Albert B. Crenshaw, In Professional Sports, States Often Claim Players; 'Jock Tax' follows Athletes to Their Places of Work, Wash. Post., Feb. 24, 2003, at D01.

145. Id.

146. See Schoettle, supra note 19, at 521 ("The state can calculate the time an athlete spends in the state without an expensive audit, can identify the employer, 
and public work schedules strikes some as unfair, especially considering that other highly paid individuals have an easier time flying under the radar. ${ }^{147}$ In addition, it is not just the highly paid athletes who bear the burden of this tax - it is also assessed against trainers, coaches, and lower-paid athletes who all travel with the team as well. ${ }^{148}$ Athletes end up paying large sums of money to accountants to help file all of their additional state income tax returns. ${ }^{149}$ Even those who are opposed to the ever-increasing salaries paid to athletes could agree that imposing taxes on people merely because they are easy to track is not fair. In addition, using the tax system as a tool in this way merely serves to drive the targets of the tax to find more ways to insulate themselves from state taxation..$^{150}$

The taxation of professional athletes has attracted a fair amount of scholarly attention, but commuters with less exciting jobs are similarly impacted. The question of the fairness of taxing, or over-taxing commuters, has been brought into stark relief in two recent cases in which New York's highest court held against two non-resident taxpayers - one, a law professor, and the other an information technology professional. ${ }^{151}$

In the first case, law professor Edward Zelinsky challenged New York's ability to tax as "source" income monies he earned while working at his home in Connecticut. Cardozo Law School - the institution for which Zelinsky taught - is located in New York. ${ }^{152}$ Zelinsky performed many of his duties, however, at his home in Connecticut. ${ }^{153}$ Zelinsky commuted three days each week during the semester, and when school was not in session and

and in general can enforce tax laws against this population with far more ease than other professionals who earn salaries from activities carried on in nonresident states.").

147. See Heath and Crenshaw, supra note 144 (quoting David K. Hoffmann, an economist with the Tax Foundation, as saying "'It's not fair [that] just because this particular occupation is so easy [to track] and no one feels bad fore [sic] the rich players that they have to pay these taxes."). But see VanderKnyff, supra note 143 (noting that states are becoming more aggressive in trying to tax CEOs and lawyers by auditing company travel records). An aggressive state revenue department could easily target trial lawyers, whose appearances in court are matters of public record. Although perhaps not as lucrative as taxing professional athletes, a trial team in a month-long, complex civil trial could easily bill in excess of a quarter of a million dollars.

148. Id.

149. Id.

150. Id.

151. Zelinsky v. Tax Appeals Tribunal of the State of New York, 801 N.E.2d 840 (N.Y. 2003), cert. denied, 541 U.S. 1009 (2004); Huckaby v. Tax Appeals Tribunal of the State of New York, 829 N.E.2d 276 (N.Y.), cert. denied, 126 S. Ct. 546 (2005).

152. Id.

153. Id. 
during his sabbatical leave in the fall semester of 1995 , he worked exclusively at home. ${ }^{154}$ Zelinsky argued that New York should be permitted to tax as source income only the percentage of income he earned while he was physically in New York. ${ }^{155}$ Similarly, Thomas Huckaby, a resident of Tennessee, worked primarily from his Tennessee home for a New York employer. ${ }^{156} \mathrm{Mr}$. Huckaby presents perhaps a more compelling case, because his time in New York was even more limited than that of Professor Zelinsky - Mr. Huckaby spent only 59 days in New York in the first tax year at issue, and only 62 days in New York in the second tax year at issue. ${ }^{157}$ Another factor making Huckaby arguably more sympathetic is that a daily commute for Huckaby would not have been just inconvenient - it simply would not have been possible. When Zelinsky prepared his tax returns, he "apportioned to New York the percentage of his total salary that reflected the number of days he commuted to the law school." ${ }^{158}$ Similarly, when Huckaby filed his returns, he "allocated his income between New York and Tennessee based on the number of days he worked in each state relative to the total number of days he worked in each tax year."159 The New York State Department of Taxation and Finance disagreed with both Zelinsky's and Huckaby's returns, and assessed deficiencies upon audit. ${ }^{160}$

In separate cases, both teleworkers challenged the deficiencies. Zelinsky raised Commerce and Due Process Clause challenges to the assessment; ${ }^{161}$ Huckaby did not raise the Commerce Clause argument, but challenged the assessments on Due Process grounds. ${ }^{162}$ The New York Court rejected both appeals, and upheld the assessments. ${ }^{163}$ The propriety of the Court's decision will be discussed below, ${ }^{164}$ what is remarkable here, however, is the criticism these decisions received in both academic and

154. Id. at 833-34. By my calculations, Professor Zelinsky spent no more than 90 days working in New York during the tax year in which he did not take a sabbatical.

155. Id.

156. Huckaby, 829 N.E.2d at $277-78$.

157. Id. at 278 .

158. Zelinsky, 801 N.E.2d at $843-44$.

159. Huckaby, 829 N.E.2d at 278.

160. Id. at 278 ; Zelinsky, 801 N.E.2d at 844.

161. Zelinsky, 801 N.E.2d at 844.

162. Huckaby, 829 N.E.2d at 281 . Mr. Huckaby also raised a statutory interpretation argument, not relevant here, that was rejected by the court. Id. at 279281.

163. Huckaby, 829 N.E.2d at 285 ; Zelinsky, 801 N.E.2d at 849.

164. See infra notes 204- 210 and accompanying text. 
popular press. ${ }^{165}$ One academic commentator noted that New York's practice of aggressively taxing non-residents such as Zelinsky and Huckaby violates "the Due Process Clause, Commerce Clause, and Privileges and Immunities Clause .. . principles." 166 In a short opinion piece published in the New York Times, the cases were criticized as unfair, and the author concluded, "The country needs telework to help address the health, energy, transportation and homeland security challenges before us, and New York's thirst for nonresident revenue simply can't take priority." 167

In addition to the fairness problem, discriminatory taxation of commuters has the potential to impact the flow of capital, impair commerce, and alter or impair individual travel and work habits. Although all taxes have some effects on individual behavior, ${ }^{168}$ discriminatory taxes can create deadweight social losses. As Daniel Shaviro explains, "When [taxes] cause a taxpayer to substitute an activity for the one she would otherwise prefer in order to reduce her tax liability, they create a deadweight social loss in the amount of the reduced pretax benefit to the taxpayer by reason of the substitution." 169 In other words, if a Connecticut resident would prefer to live in Connecticut and work in New York City, but because of double taxation she either foregoes the New York job, or moves to New York, a deadweight social loss is created. This inefficiency and corresponding deadweight losses

165. See, e.g., Molly McDonough, Telecommuter Tax Case is Closely Watched, 4 A.B.A. Journal Report 2 (Jan. 14, 2005) (calling the case "closely watched" and noting that "upwards of $\$ 100$ million in tax revenue" was at stake).

166. William V. Vetter, A Critique of The Empire State's "New" Convenience of the Employer Rule, J. of Multistate Taxation \& Incentives 14, 23 (Feb. 2007). See also Meredith A. Bentley, Huckaby v. New York State Division of Tax Appeals: In Upholding the Current Tax Treatment of Telecommuters, the Court of Appeals Demonstrates the Need for Legislative Action, 80 St. John's L. Rev. 1147, 1166 (2006) (criticizing the decisions in Huckaby and Zelinsky, and concluding that "the onus is on the legislature to put an end to the unfair tax treatment of telecommuters").

167. Nicole Belson Goluboff, Taxing Telecommuters, N.Y. Times, Aug. 6, 2006 , at $\S 14 \mathrm{CN}$, at 13 .

168. Shaviro, Federalism in Taxation, supra note 94 , at 900 ("taxes inevitably have income effects - by reducing the taxpayer's wealth, they affect her behavior").

169. Id. See also President's Advisory Panel on Federal Tax Reform, Simple, Fair, and Pro-Growth: Proposals to Fix American's Tax System 36 (2005) [hereinafter President's Advisory Panel], available at http://www.taxreformpanel.gov /final-report/TaxReform_Ch3.pdf (explaining efficiency costs as follows: "When taxpayers change their behavior to minimize their tax liability, they often make inefficient choices that they would not make in the absence of tax considerations. These tax-motivated behaviors divert resources from their most productive use and reduce the productive capacity of our economy."). 
"waste economic resources, reduce productivity, and, ultimately lower living standards for all." 170

Despite all the drags that double-taxation puts on our national economy, states remain sorely tempted to export taxes and generate revenues from non-residents. States often give in to that temptation, after all, the demands on states' fiscs continue to grow, and non-residents who earn substantial revenue in the state present what must appear to legislators and revenue authorities as a bull's eye target as they drive across the state line to come to work. ${ }^{171}$ This problem of tax exportation promises to continually become worse as our economy becomes ever more integrated. ${ }^{172}$

Non-residents, of course, are also non-voters, and as such, have a much more difficult time finding relief in the state legislature. ${ }^{173}$ Nonresidents historically have also faced a difficult time finding relief in the Congress. ${ }^{174}$ Although a recent bill, The Telecommuting Tax Fairness Act, has been introduced in both the House and Senate, ${ }^{175}$ Congressional intervention in state and local tax matters has been nearly nil over the two

170. President's Advisory Panel, supra note 167, at 36 . A telling example of such deadweight social losses was recently reported by the New York Times. CBS C.E.O. Leslie Moonves amended his contract with CBS so that CBS will pay any state or local taxes Moonves might incur by living in California but occasionally working in New York. Patrick McGeehan, Getting Too Big For His Own Taxes?, N.Y. Times, Aug. 26, 2007 at B2. These legal costs and related expenses would be unnecessary if Mr. Moonves could rely on consistent tax treatment.

171. New York's revenue department is notorious for its aggressive collection practices. See, e.g., Nicole Belson Goluboff, New York Makes it Official: Double Taxing of Telecommuters Will Continue, 40 St. Tax Notes 877, 877-79 (2006) (urging Congress to "remind New York that the state's hunger for nonresident revenue does not trump the nation's need to prepare for emergencies" such as pandemic flu and energy crises).

172. Shaviro, Federalism in Taxation, supra note 94, at 902 ("Today's more integrated national economy presents far greater opportunities than existed in 1787 for states in effect to reach across their borders and tax nonconsenting nonbeneficiaries.")

173. E.g., Metzger, supra note 113, at 1484 (noting "It seems fair to expect that states will downplay harms to out-of-state interests for in-state gain, at least when out-of-state interests lack effective in-state surrogates.").

174. See Shaviro, Federalism in Taxation, supra note 94, at 897 . But see Kaye, supra note 124 , at 54, 66-67 (noting a "historic reluctance of Congress to intervene in state taxation" but also noting that "in the last decade, there has been an increase in interference with state tax systems").

175. Telecommuter Tax Fairness Act of 2007, H.R. 1360, 110th Cong. (2007); S. 785, 110th Cong. (2007). Both bills were introduced by Connecticut politicians: Representative Chris Shays and Senator Chris Dodd. 
hundred years of union. ${ }^{176}$ Commentators dispute whether Congress would adequately protect state interests in this realm. Tracy A. Kaye, for example, argues that "Congress is causing more harm than good in the name of avoiding tax discrimination and should exercise the legislative restraint it historically had shown to the taxing powers of the states." ${ }^{\prime 177}$ Another respected scholar, Edward Zelinsky argues, on the other hand, that it is time to restore politics to the dormant Commerce Clause and "scrap the dormant Commerce Clause prohibition on discriminatory taxation." 178 Zelinsky suggests that taxpayers with complaints about discriminatory taxation take those complaints to "Congress or to the legislature imposing those taxes."

Regardless of whether Congress would adequately protect states' interests, or the interests of individual commuters, nonresidents challenging state taxes have had little success in Congress. Similarly, nonresident taxpayers have had relatively little success in their complaints to state courts or in the United States Supreme Court. Nonresidents face potentially hostile state courts - courts with at least some incentive to protect the treasury on which their paychecks are drawn. Nonresident taxpayers might avoid the risk of parochial state courts by bringing suit in federal court, however, litigants must clear several hurdles to successfully maintain a suit in federal court. This is no easy task. First, the taxpayer must surmount the Tax Injunction Act, ${ }^{180}$ the federal statute prohibiting federal courts from enjoining the collection of state taxes unless there is no adequate state court remedy. The Tax Injunction Act has been interpreted "liberally to impose a strict bar on federal court jurisdiction to entertain challenges to state taxes, except in the rare situation where the plaintiff can demonstrate that it has no adequate

176. See Shaviro, Federalism in Taxation, supra note 94, at 897 (noting that "for two hundred years Congress has almost never used these [Commerce Clause] powers to constrain state and local discretion in the tax area").

177. Kaye, supra note 124 , at $70-71$. Kaye marshals the legislation that Congress has been willing to pass, including the State Taxation of Pension Income Act of 1995 (preventing states from taxing certain retirement income of former residents) and the Internet Tax Freedom Act (ITFA) (preventing certain sales taxes on internet access and on some internet purchases) to conclude that "Congress does not represent the states and there is increasing temptation to enact legislation that benefits a select constituency at a revenue cost to the states." Id. at 70 .

178. Edward A. Zelinsky, Restoring Politics to the Commerce Clause: The Case for Abandoning the Dormant Commerce Clause Prohibition on Discriminatory Taxation, 29 Ohio N.U.L. Rev. 29, 29 (2002) [hereinafter Restoring Politics]. See also Edward A. Zelinsky \& Brannon Denning, The Future of the Dormant Commerce Clause: Abolishing the Prohibition on Discriminatory Taxation, $155 \mathrm{U}$. Pa. L. Rev. PENNumbra 196 (2007)..

179. Id. at supra note 176 , at 30 .

180. 128 U.S.C. $\$ 1341$. 
remedy in the state courts." ${ }^{\text {181 }}$ Even if the taxpayer meets the strictures of the Tax Injunction Act, the challenger must also satisfy federal prudential and constitutional standing requirements, and the Court has been parsimonious in permitting taxpayer standing. ${ }^{182}$

Even if a taxpayer has standing, another challenge taxpayer litigants face is the perception, if not the reality, that the Supreme Court is more deferential to states when states are exercising their taxing authority than in other instances of challenges to state power. ${ }^{183}$ One explanation for that deference is that the Supreme Court "regards the power to tax as at the heart of a government's sovereignty." 184 Indeed, a sovereign's "authority to impose taxes is one of its most pervasive and fundamental powers." 185 Even if the taxpayer finds a friendly state court, or can maintain an action in federal court, yet another intensely practical hurdle exists - money. The costs of bringing litigation to challenge a tax collection will frequently outweigh the potential reward for an individual taxpayer. ${ }^{186}$

181. Hellerstein \& Hellerstein, supra note 7, at 1114 (citing California v. Grace Brethren Church, 457 U.S. 393, 411 (1982) (“[B]ecause Congress' intent in enacting the Tax Injunction Act was to prevent federal-court interference with the assessment and collection of state taxes, we hold the Act prohibits declaratory as well as injunctive relief"). See also Kaye, supra note 124, at 55 (noting that "In the U.S. judicial system, taxpayers normally have to challenge a state tax in state court.").

182. E.g., DaimlerChrysler Corp. v. Cuno, 126 S. Ct. 1854 (2006) (dismissing for lack of standing where state taxpayers' claims that a particular tax incentive violated the Commerce Clause); Kristin Hickman, How Did We Get Here Anyway? Considering the Standing Question in DaimlerChrysler v. Cuno, 4 Geo. J.L. \& Pub. Pol'y 47 (2006). See also Hein v. Freedom From Religion Foundation, Inc., 127 S. Ct. 2553, 2559 (2007) (discussing the limitations of taxpayer standing).

183. See Shaviro, Federalism in Taxation, supra note 94, at 942 (discussing this perception).

184. Id. Shaviro continues, "Another explanation is that the Court simply lacks confidence in its ability to understand tax cases and resolve them intelligently, and thus prefers to let most challenged tax cases stand." Id. This second explanation is less persuasive. Although the Supreme Court might lack confidence to tackle highly technical federal income taxation questions, it is unlikely that the Court lacks confidence in its ability to discem questions of constitutional law, and it is questions of constitutional law that many state and local tax disputes raise. The authors of the leading textbook on state and local taxation, Hellerstein \& Hellerstein, dedicate the majority of the book to constitutional questions.

185. Stephen W. Mazza \& Tracy A. Kaye, Restricting the Legislative Power to Tax in the United States, 54 AM. J. Comp. L. 641, 641 (2006) (citing The Federalist No. 33 (Alexander Hamilton) (describing the power to tax as the most important of the legislative powers)).

186. E.g., Javor v. State Bd. of Equalization, 527 P.2d 1153 (Cal. 1974) (permitting a class action challenging a state sales tax because "[ $t]$ he amount due each member of the class is relatively small and when compared with the costs of 


\section{B. Constitutional Norms and Commuting}

With the perils of double-taxation firmly in mind, the article now turns to a more specific exploration of how the Constitution protects our national economy from double-taxation. This part explains why the Commerce Clause ${ }^{187}$ applies to this question, and then turns to the Constitutional overlap of the Commerce and Privileges and Immunities Clauses.

\section{The Interstate Market for Employees}

It is somewhat awkward to consider commuters - people - as articles of commerce. Nonetheless, it is "settled beyond question" that individuals are indeed articles of commerce, at least for dormant Commerce Clause analysis. ${ }^{188}$ Perhaps it is less unseemly to think about the Commerce Clause as protecting the market in which states compete for residents£ or the market in which employers compete for employees. The dormant Commerce Clause trigger is flipped regardless of whether we consider the teleworkers articles of commerce themselves or we consider the market for those workers the triggering event. In any case, given the clear impact on interstate commerce, there is no persuasive reason that the Complete Auto Transit test should not apply to individual personal income taxation just as it applies to taxation of business income. The historic purpose of the clause dictates that it applies to

suit, would discourage individual legal actions."). Note, too, that "in the absence of a waiver of immunity, the taxpayer cannot ordinarily recover interest on an unconstitutional levy." Hellerstein \& Hellerstein, supra note 7, at 1096.

187. See generally Walter Hellerstein, Reconsidering the Constitutionality of the "Convenience of the Employer" Doctrine, 2003 State Tax Today 235-16 (May 12 , 2003) (suggesting that the Due Process clause prevents states from taxing individual income on an unapportioned basis when that income is earned in another state which also has power to tax a portion of the income).

188. Edwards v. California, 314 U.S. 160, 172 (1941); Mary Sarah Bilder, The Struggle Over Immigration: Indentured Servants, Slaves, and Articles of Commerce, 61 Mo. L. Rev. 743, 745 (1996) (asserting that "People are articles of commerce, or so the United States Supreme Court held in 1941, emphasizing that the issue was 'settled beyond question." (quoting Edwards, 314 U.S. at 172)). Bilder notes the uneasiness that comes with considering individuals to be items of commerce, she cites Justice Jackson's discomfort with the theory that "the migrations of a human being . . a are commerce." Id. (citing Edwards, 314 U.S. at 182 (1941) (Jackson, J., concurring)). Bilder's article demonstrates good reason for that discomfort; she argues that "the Court's nineteenth-century opinions on immigration under the Commerce Clause reveal the shadows of slaves and indentured servants." Id. at 749. 
interstate commuters' plight. ${ }^{189}$ That the Dormant Commerce Clause Doctrine applies is even clearer after consideration of recent case law, including the Court's opinion in Camps Newfound/Owatonna v. Town of Harrison. ${ }^{190}$ Rather than pre-empting application of the dormant Commerce Clause to our commuter's complaint, the Privileges and Immunities Clauses of both Article IV and the 14th Amendment complement, and provides an independent constitutional means for relief for our commuter.

\section{Historic Purposes and Modern Commuters}

Over 200 years after Alexander Hamilton and James Madison expressed their concerns about economic competition between the states, the national economy has not (yet) been destroyed by state rivalries. ${ }^{191}$ As states fund increasingly expensive and expansive services, however, they must turn more and more to increasing taxes to generate revenue. ${ }^{192}$ As the pressure to raise revenue grows, states compete with each other to try to attract more business and more high-income-earning residents. ${ }^{193}$ This competition not only implicates Hamilton and Madison's concerns about harm to national unity, but also can leave interstate commercial actors, including teleworkers, fending off attempts by states to tax more than a fair share of their income.

By its terms, the Complete Auto Transit test applies to cases involving taxation of businesses engaged in interstate commerce. The Court has not used the Complete Auto Transit test to analyze an individual person's interstate commercial activity, at the same time, the Court has not expressly held that the four-part test does not apply to the taxation of individual

189. But c.f., Bernard E. Jacob, An Extended Presence, Interstate Style: First Notes on a Theme From Saenz, 30 Hofstra L. Rev. 1133, 1237 (2002) (arguing that the Commerce Clause doesn't need to cover this situation, because "At least as high a standard of protection is or ought to be available under the 14th Amendment.").

190. 520 U.S. 564, 572 (1997).

191. C.f., Peter D. Enrich, Saving the States From Themselves: Commerce Clause Constraints on State Tax Incentives for Business, 110 Harv. L. Rev. 377 (1996) (suggesting that the national economy has in fact been damaged by such rivalries).

192. Hellerstein \& Hellerstein, supra note 7, at v (noting that since 1952 tax revenues collected by state and local governments have increased almost fifty-fold; an "astronomical tax increase[]" that "reflect[s] comparable increases in state and local government expenditures" attributable in part to inflation but also in substantial part to "the broadening of the nature and scope of state and local government services").

193. E.g., Enrich, supra note 191, at 377 (discussing the "vicious cycle" of state and local incentives and its pernicious effect on interstate relations and on the states themselves). 
income. ${ }^{194}$ At least one state court to address the question, however, insists that the dormant Commerce Clause does not apply to the taxation of individual income. ${ }^{195}$ The New York Court of Appeals continues to maintain that " $[t]$ he taxpayer's crossing of state lines to do his work at home simply does not impact upon any interstate market in which residents and nonresidents compete so as to implicate the Commerce Clause."196 This conclusion does not withstand scrutiny.

Though the Supreme Court has not expressly held that commuting trips the dormant Commerce Clause test, the Court has noted that the crossing of state lines by individuals constitutes interstate commerce. ${ }^{197}$ The Court has also long recognized that individual activity can affect interstate commerce when looked at in the aggregate. ${ }^{198}$ It does not matter that the imposition on commuters impacts only a portion of the stream of interstate commerce: "The imposition of a differential burden on any part of the stream of commerce - from wholesaler to retailer to consumer - is invalid, because a burden placed at any point will result in a disadvantage to the out-of-state producer." 199

The Supreme Court's recent opinion in Camps Newfound/Owatonna v. Town of Harrison supports the application of the dormant Commerce Clause to the taxation of commuters' income. In Camps Newfound, the

194. The question was raised in the appeal from Zelinsky, but the Court denied certiorari. The petition for certiorari posed the question as follows: “1) On days when New York's "convenience of the employer" rule risks double taxation of nonresident telecommuters for working at their out-of-state homes, does that rule, and the risk of double taxation the rule causes, violate the Commerce Clause? 2) On days when New York's "convenience of the employer" rule risks double taxation of nonresident telecommuters for working at their out-of-state homes, does that rule, and the risk of double taxation the rule causes, violate the Due Process Clause?" Petition for certiorari at i, Zelinsky, 541 U.S. 1009, 2004 WL 322430.

195. Zelinsky v. Tax Appeals Tribunal of the State of New York, 801 N.E.2d 840, 847 (N.Y. 2003), cert. denied 541 U.S. 1009 (2004).

196. Zelinsky, 801 N.E.2d at 847. The court's position in Zelinsky is even more confounding considering the court's previous holding in City of New York v. State of New York, 94 N.Y.2d 577,597 (2000) that transportation of persons is interstate commerce.

197. Camps Newfound/Owatonna, Inc. v. Town of Harrison, 520 U.S. 564, 572 (1997) (disagreeing with the Town's argument that campers are not articles of commerce). The Court has addressed so-called "commuter taxes." A commuter tax is essentially an entry tax on out-of-state workers. In Austin v. New Hampshire the Court struck down these blatantly discriminatory taxes. 420 U.S. 656 (1975).

198. See Wickard v. Filburn, 317 U.S. 111 (1942). See also Camps Newfound/Owatonna, 520 U.S. at 586 ("The interstate commercial activities of nonprofit entities as a class are unquestionably significant.").

199. Camps Newfound/Owatonna, 520 U.S. at 580 (quoting West Lynn Creamery v. Healy, 512 U.S. 186, 202 (1994)). 
Court held that a Maine property tax exemption for charitable organizations which excluded charities operated principally for the benefit of non-residents violated the dormant Commerce Clause. ${ }^{200}$ The Court rejected the town's argument that campers were not "articles of commerce," and invoked the dormant Commerce Clause, noting that campers' travel to attend the camps "necessarily generates the transportation of persons across state lines that has long been recognized as a form of "commerce.", ${ }^{201}$ Rejecting the notion that economic protectionism includes only state attempts to provide advantages to in-state merchants, the Court noted that it also may include attempts to provide advantages to in-state consumers. ${ }^{202}$

The Court reiterated that "a State may not tax a transaction or incident more heavily when it crosses state lines than when it occurs entirely within the State." 203 Finding the Maine property tax exemption to be facially discriminatory, ${ }^{204}$ the Court strictly scrutinized, and subsequently struck down, the exemption statute. ${ }^{205} \mathrm{~A}$ few campers choosing to camp in one state or another might appear trivial, and not a threat to the national economy. But the Court reminds us that the facts must be considered in the aggregate, and in the aggregate, there is no doubt that summer campers impact commerce. ${ }^{206}$

Camps Newfound illustrates how the Zelinsky court erred. ${ }^{207}$ The Zelinsky Court supports its conclusion by suggesting that because it is a personal decision to live in Connecticut, and work in New York, the Commerce Clause is not implicated. ${ }^{208}$ This conclusion misses the point. Just as the camper's choice, most likely for personal reasons, to cross state lines in Camps Newfound triggered dormant Commerce Clause scrutiny of a tax,

200. Id.

201. Id.

202. Id.

203. Id.

204. Id.

205. Id. at 583 n. 16.

206. Id.

207. The plaintiffs urged the New York Court to consider the Supreme Court's opinion in Camps Newfound. See Reply Brief of the Appellants Edward A. And Doris Zelinsky at 2, 4, Zelinsky v. tax Appeals Tribunal for the State of New York, 801 N.E.2d 840, 847 (N.Y. 2003), cert. denied 541 U.S. 1009 (2004). Inexplicably, the Zelinsky Court did not cite or discuss Camps Newfound. Walter Hellerstein provided an earlier critique of the intermediate court's decision in the Zelinsky case. See Walter Hellerstein, Reconsidering the Constitutionality of the "Convenience of the Employer" Doctrine, 2003 State Tax Today 235-16 (May 12, 2003).

208. Zelinsky v. Tax Appeals Tribunal of the State of New York, 801 N.E.2d 840, 847 (N.Y. 2003), cert. denied 541 U.S. 1009 (2004). The Zelinsky court distinguished Austin v. New Hampshire, 420 U.S. 656, 665-68 (1975), in which the Court held that state imposition of higher tax rate for nonresidents violates the Privileges and Immunities Clause. 
so too does the crossing of state lines by commuters like Zelinsky. The impact of commuters on the national economy cannot be denied. As one leading Federal Income Tax text puts it, "[t]he mobility of labor is an important and necessary part of the nation's economy, since it reduces unemployment and increases productive capacity.",209

The Zelinsky court referred to commuting as a "personal choice" of the taxpayer. ${ }^{210}$ No doubt personal preference plays a role in where to live and to some extent where to work. Indeed, the federal tax code considers commuting to be a "personal" expense, and does not allow deductions for commuting. ${ }^{211}$ At first blush, the federal treatment of commuting expenses as personal might provide fodder for the conclusion that interstate commuting does not trigger the Commerce Clause. The lack of a federal deduction for commuting expenses, however, has been criticized as disingenuous. As one casebook puts it, "If it is a 'personal' decision to decide where to live, it is equally a 'business' decision to decide where to work." ${ }^{212}$ In fact, the goal of neatly separating expenses into business (and therefore deductible) and personal (and therefore not deductible) is subject to cogent criticism. ${ }^{213}$ Furthermore, the decision to deny a personal income tax deduction for commuting expenses is efficient: whether a person chooses a long commute or a short commute, her tax liability will not change as a result of her decision, and thus tax considerations should not impact her choice. Double

209. Klein, Bankman, \& Shaviro, supra note 12, at 445 (citing a 1970 Congressional Report).

210. Zelinsky, 801 N.E.2d at 847 (noting that Zelinsky's “voluntary choice to bring auxiliary work home to Connecticut cannot transform him into an interstate actor").

211. Treas. Reg. $\S \S 1.162-2(e), 1.262-1(b)(5)$ (2007); Klein, Bankman, \& Shaviro, supra note 12 , at 445 . The federal government does, however, allow taxpayers to elect to use up to $\$ 215$ a month in pre-tax wages to pay for their parking at work. William Neuman, Mixed Signals: Driving to Work as a Tax Break, N.Y. Times, Aug. 16, 2007, at A1. At the same time, as the Neuman article points out, the federal government has recently made it a priority to discourage people from driving. The tax-break for parking, coupled with the new Department of Transportation grants to discourage driving is described as a "perverse" example of government policies working at cross-purposes. Id.

212. Klein, Bankman, \& Shaviro, supra note 12, at 445.

213. E.g., Mary Louise Fellows, Rocking the Tax Code: A Case Study of Employment-Related Child-Care Expenditures, 10 Yale J.L. \& Feminism 307, 38893 (1998) (arguing that the "business/personal distinction does not produce predictable and widely accepted results" and further observing that "the difficulty of distinguishing business and personal expenditures is far more complex than merely a problem of determining taxpayer intent. The problem with the distinction is that it marks business expenses as productive, and personal expenses as unproductive in a way that misapprehends productivity in the home and nonproductivity in the marketplace."). 
taxation of nonresident commuters, however, is inefficient. If a person faces double taxation as a result of his decision to live in one state and work in another, his tax liability will be affected by his choice, and tax considerations almost certainly will impact his decision of whether to maintain this arrangement. Rather than making his choices of where to live and work free of tax considerations, his decision will now be impacted by the knowledge that he could avoid double taxation by moving to the state of employment or finding a new job in the state of residence.

Taxpaying commuters challenging discriminatory taxation could find an unlikely ally in Justice Scalia, elsewhere a vehement opponent of the Court's Dormant Commerce Clause Doctrine. Scalia's dissent in Camps Newfound makes clear that he is willing to apply the doctrine to overrule state taxes that facially discriminate against interstate commerce. ${ }^{214}$ Particularly, Scalia quoted Justice Jackson's statement in H.P. Hood \& Sons, Inc. v. Du Mond that the "vision of the Founders" was "that every farmer and every craftsman shall be encouraged to produce by the certainty that he will have free access to every market in the Nation . . . "215 While Scalia argued against the applicability of the Dormant Commerce Clause Doctrine to the Maine tax in Camps Newfound, the tax in the case was not truly an economic protectionist measure in the way that aggressive taxation of interstate commuters is protectionist, and thus his opposition to the use of the Dormant Commerce Clause Doctrine in that situation is unlikely to carry over to a commuter tax apportionment situation. Scalia thought that the Maine statute was best viewed as "a narrow exemption for organizations that provided services the state might otherwise provide." ${ }^{, 216} \mathrm{He}$ did not think that providing a tax break to an organization that relieved the state of providing social services was something that implicates interstate commerce. ${ }^{217}$

The concept that the Commerce Clause protects the right of every farmer and craftsman to have free access to every market in the nation is not just an anachronism; the concept is commonplace in judicial decisions today. The Eighth Circuit decided Jones v. Gale in 2006, holding that a Nebraska constitutional amendment prohibiting corporations or syndicates from acquiring interests in Nebraska real estate used for farming or ranching (with certain exceptions) violated the dormant Commerce Clause by favoring Nebraska residents and people who were in close enough proximity to Nebraska farms and ranches to make a daily commute. ${ }^{218}$ The court

214. See Hellerstein \& Hellerstein, supra note 7, at 206.

215. Camps Newfound/Owatonna, 520 U.S. at 595 (Scalia, J., dissenting).

216. Karin J. Kysilka, Recent Development: A Jurisdictional Vacuum in the Wake of Camps Newfound/Owatonna?, 21 Harv. J. L. \& Pub. Pol'y 288, 294 (1997).

217. Id. at 294.

218. Jones v. Gale, 470, F.3d 1261, 1264-65 (8th Cir. 2006). 
particularly noted the advertisements that had run during the ballot initiative to adopt the constitutional provision, which encouraged people to vote for it in order to "send a message to those rich out-of-state corporations." ${ }^{219}$ The court did not find any of the state's proffered non-discriminatory reasons for adopting the provision to outweigh the harm done by denying non-residents access to the Nebraska farm market. ${ }^{220}$ The Jones v. Gale decision explicitly applies the Commerce Clause to interstate commuters.

As commuting across state lines becomes a more common work arrangement, states are unsurprisingly able to take advantage of the situation to reap more than may be fair from non-resident employees. The world of work has changed since the time of the drafting of the Constitution. ${ }^{221}$ People are able to live in one state and work in a place much farther away than would have been possible years ago. ${ }^{222}$ As cities and states compete to attract workers to strengthen their economies, ${ }^{223}$ they also face the increasing ability of workers to separate the choice of where to live from the choice of where to work. ${ }^{224}$ By placing a greater tax burden on people who work in their state but not live there, states with many commuter employees are able to provide themselves with some protection in the market for residents, as well as the market for workers, ${ }^{225}$ in contravention of the principles behind the Commerce Clause.

219. See id. at 1270 .

220. Id. at 1267-69. The Jones v. Gale decision is open to criticism on a number of counts-including the Court's questionable assessment that the anticorporate farming provision purposefully discriminated against interstate commerce. The case is cited here not because it is necessarily a persuasive example of dormant Commerce Clause jurisprudence, but simply to illustrate how courts are analyzing the issue.

221. See generally Hellerstein \& Hellerstein, supra note 8, at 192 ("With the rapid growth of large-scale industry and the foreshortening of distances through modern transportation and communication, state lines lost much of their economic importance. At the same time the increasing demands upon the states for schools, roads, relief, and other social services forced them to seek out every available source of revenue.")

222. See, e.g., David Schultz, 16 Touro L. Rev. 435, 435 (2000) ("The nature of work and employment in America has changed dramatically in the last twenty to thirty years. . . . People often choose or are required to work in certain places that are located in a different jurisdiction, county, or state from where they live.").

223. See, e.g., Shaila Dewan, Cities Compete in Hipness Battle to Attract Young, N.Y. Times, Nov. 25, 2006, at A1; Karen Brune Mathis, To Keep Young Workers, Keep Attention on Downtown, Fla. Times-Union (Jacksonville), Feb. 24, 2006, at D1.

224. See Schultz, supra note 222.

225. See Dewan, supra note 223; Mathis, supra note 223. Cf. Christina Gostomski, More Local Income Taxes May Go Unpaid, Morning Call (Allentown, 


\section{Constitutional Overlap}

Although the Commerce Clause "provides the strongest constitutional bulwark against hostile state regulation and taxation of the national economy"227 it is not the only constitutional norm implicated by the situation of our double-taxed commuting taxpayer. Indeed, academic commentators, and the Court itself have found a "mutually reinforcing relationship between the Privileges and Immunities Clause of Article IV, section 2, and the Commerce Clause - a relationship that stems from the common origin in the Fourth Article of the Articles of Confederation and their shared vision of federalism." 228 As one scholar recently phrased it, "[w] here economic activity of nonresident individuals is involved, the demands of the dormant Commerce Clause and Article IV largely overlap.",229

That interstate commuting taxpayers may appeal to the Commerce Clause to challenge discriminatory taxation does not mean that the Privileges and Immunities Clause has no place in the double-taxed commuter's arsenal. The Article IV Privileges and Immunities Clause is in fact the more typical

Pa.), May 6, 2007, at Al (discussing the high amount of unpaid Pennsylvania local income taxes and noting that a major source of the problem is the increase of nonresident employees from neighboring states).

226. See Paul J. Hartman, State Taxation of Corporate Income from a Multistate Business, 13 Vand. L. Rev. 21, 21-22 (1960), quoted in Hellerstein \& Hellerstein, supra note 7 , at 193 :

If one state in order to supply her fiscal needs or promote the commercial and economic well-being of her citizens may shield them from competition from sister states by the taxing process, we have opened a Pandora's box of troubles in the nature of reprisals and trade wars that were meant to be averted by subjecting commerce among the states to the power of the federal government.

227. Jim Chen, A Vision Softly Creeping: Congressional Acquiescence and the Dormant Commerce Clause, 88 Minn. L. Rev. 1764, 1764 (2004). But see Hicklin v. Orbeck, 437 U.S. 518, 524 (1978) (referring to the privileges and immunities clause: "It has been justly said that no provision in the Constitution has tended so strongly to constitute the citizens of the United States one people as this.").

228. Hicklin, 437 U.S. at 531-32. See also Laycock, supra note 21, at 259, 270 (noting that "Much of the Constitution addresses the task of creating one nation out of separate states, and of doing so without abolishing those states." Further noting that "The same constitutional principles of national unity and interstate equality are at work in all three [Commerce, Privileges and Immunities, and Equal Protection] clauses.").

229. Metzger, supra note 113, at 1507. 
clause trotted out when a state seeks to prohibit or restrict nonresidents from working within the State's borders. ${ }^{230}$ The Privileges and Immunities Clause expressly protects the rights of nonresidents. ${ }^{231}$

Because the Privileges and Immunities Clause speaks quite directly to the treatment of interstate commuters, it has been argued that the dormant Commerce Clause cannot also apply. ${ }^{232}$ Such an argument rests on cannons of statutory construction, and particularly on the notions that implied language cannot trump express language in the same legal document and that implied repeals are strongly disfavored. ${ }^{233}$ It is unclear, however, that the "regular" rules of statutory construction apply with equal force to interpretation of the Constitution. ${ }^{234}$ Our Constitution is, after all, a unique document. ${ }^{235}$ Scholars have wondered whether "special canons of construction, not applicable to any ordinary legal documents, [can] be derived from the Constitution's unique context and purpose?"236 Even if the generic rules of construction apply, however, the better reading is that the Commerce Clause and Privileges and Immunities Clauses should be read in concert, rather than in tension. It is not the case that the protections afforded by the Commerce Clause repealed those provided by the Privileges and Immunities clause.

It is the combination of these clauses - read together in both historic context and as the clauses have developed along with our national economy, that I wish to emphasize. Read together, these clauses provide a sound argument for our weary and overtaxed commuter. As one scholar put it, "[ $t]$ he non-discrimination component of right to travel case law introduces an element of affinity with the Dormant Commerce Clause Doctrine and the privileges and immunities clause." ${ }^{237}$ The interaction of these constitutional

230. See infra notes 89 to 114 and accompanying text discussing the history of the Privileges and Immunities Clause. See also Robert J. Firestone, Does a Commuter's Choice of Where to Reside Implicate the Dormant Commerce Clause?, 49 N.Y.L. Sch. L. Rev. 943 (2004-2005) (suggesting that because the Privileges and Immunities Clause applies, the dormant Commerce Clause should not apply to protect the interests of interstate commuters).

231. See infra.

232. Firestone, supra note 227 , at 943.

233. Id. at $950-51$.

234. E.g., Caleb Nelson, Originalism \& Interpretive Conventions, $70 \mathrm{U}$. Chi. L. Rev. 519, 555 -556 (2003) (noting the radical nature of our written constitution and asking, "Did such a document trigger the rules of interpretation applicable to an ordinary statute? To a treaty? To a contract?").

235. Id. at 556.

236. Id. (further asking "If so, what were those canons?")

237. Francesca Strumia, Citizenship and Free Movement: European and American Features of a Judicial Formula for Increased Comity, 12 Colum. J. Eur. L. 713,715 (2006). 
principles in case law results in a doctrine of unconstrained travel that is largely indebted to ideas of non-discrimination and equal citizenship.",238

Just as the word "travel" is not found in the Constitution, neither is the word "commute." ${ }^{, 239}$ Nonetheless, just as the right to travel is a "virtually unconditional personal right, guaranteed by the Constitution to us all"240 so too is the right to pursue a common calling, unencumbered by protectionism or discrimination of sister states. As the Court explained, "every farmer and every craftsman shall be encouraged to produce by the certainty that he will have free access to every market in the Nation, that no home embargoes will withhold his exports, and no foreign state will by customs duties or regulations exclude them." ${ }^{241}$ This system benefits our national residents as both producers and consumers, as the Court continued, "every consumer may look to the free competition from every producing area in the Nation to protect him from exploitation by any. Such was the vision of the Founders; such has been the doctrine of this Court which has given it reality."242

The dormant Commerce Clause doctrine, and the Privilege and Immunities clauses share a common origin and a common goal of federalism, but the Privileges and Immunities Clause arguably has even more lofty ambitions than the Commerce Clause. While the Commerce Clause is concerned primarily with markets and economics, the Privileges and Immunities Clause ("commercial flavor" ${ }^{243}$ though it may have) has as its goal "social, economic, and political unity and national identity." 244 The protection from double taxation is "not based on the Interstate Commerce Clause after Saenz, but on national citizenship, the right to travel and National Privileges or Immunities Clause of the 14th Amendment. 245

238. Id.

239. Saenz v. Roe, 526 U.S. 489,498 (noting that the word "travel" is not in the constitution).

240. Id.

241. H.P. Hood \& Sons, Inc. v. Du Mond, 336 U.S. 525, 539 (1949).

242. Id.

243. Metzger, supra note 113, at 1503.

244. Francis J. Conte, Sink or Swim Together: Citizenship, Sovereignty, and Free Movement in the European Union and the United States, $61 \mathrm{U}$. Miami L. Rev. 331, 354 (2007) (arguing that "the American free movement is more robust than that currently enjoyed within the European Union, and its animating purpose social, economic, and political unity and national identity - is much broader than the European Union's 'economic integration' purpose.")

245. Jacob, supra note 189 , at 1237 . Jacob continues: "The bite of the state 'double taxation' that is inconsistent with national citizenship is that it becomes due solely by reason of the several states' indifference to the taxpayer's reasons for assigning residential and work places in different states." Id. 


\section{CONCLUSION}

If, as this article argues, the Constitution limits multiple taxation of commuters' income, what solution is there for states? States must be permitted to exercise their taxing power, and if a State chooses to do so, it should be permitted to exercise that authority up to the constitutional limit. One solution would be to require states to apportion source income - that is, when two or more states have a legitimate claim to consider income "sourced" to their state, those states could be required to apportion only a percentage of that income to themselves. States are familiar with apportionment of business taxation, and could apply that regime to the taxation of individual income. ${ }^{245}$

Congress could solve the problem expeditiously by using its Commerce Clause powers to put an end to discriminatory taxation. ${ }^{246}$ Congress could require states to apportion source income, or perhaps a more drastic, but more administratively feasible solution would be for Congress to

245. This apportionment argument is not unique to taxation, and in fact has been applied to voting: Sanford V. Levinson "proposed that commuters and others who have contacts with more than one state be allowed to vote in more than one place, perhaps apportioning one vote over several jurisdictions." Douglas Laycock, Equal Citizens of Equal \& Territorial States: The Constitutional Foundations of Choice of Law, 92 Colum. L. Rev. 249, 337 n.142 (1992) (citing Sanford V. Levinson, Suffrage and Community: Who Should Vote?, 41 Fla. L. Rev. 545, 55154 (1989)). Laycock agrees in principle to allowing commuters "to apportion a single vote among more than one jurisdiction" but would "object only on grounds of workability." Id.

246. This article does not attempt to address the question of whether Congress could do the opposite-authorize discriminatory taxation of interstate commuters' income. If the freedom from discriminatory taxation rests on the Privileges and Immunities clauses, it is unlikely that the Congress could authorize states to discriminate. Compare Michael P. O'Connor, Time Out of Mind: Our Collective Amnesia about the History of the Privileges or Immunities Clause, $93 \mathrm{Ky}$. L. J. 659, 719 (2005) ("Saenz v. Roe makes clear that congressional power is limited by the Privileges or Immunities Clause.") and Jim Chen, A Vision Softly Creeping: Congressional Acquiescence and the Dormant Commerce Clause, $88 \mathrm{Minn}$. L. Rev. 1764, 1773-77 (2004) (arguing that Congress lacks authority to authorize Article IV Privileges and Immunities violations) with Gillian E. Metzger, Congress, Article IV, and Interstate Relations, 120 Harv. L. Rev. 1468 (2007) (exploring whether Congress has the power to authorize states to engage in conduct that otherwise would violate Article IV and concluding that in some circumstances, Congress does have such power). If the only constitutional norm implicated is the Commerce Clause, then it is more likely that Congress can authorize discrimination. But see Norman R. Williams, Why Congress May Not "Overrule" the Dormant Commerce Clause, 53 UCLA L. Rev. 153, 159 (2005) ("In short, the Dormant Commerce Clause may not be overridden by Congress."). 
prohibit states from taxing the compensation of a nonresident when the nonresident is not physically present in the state - as the proposed Telecommuter Tax Fairness Act of 2007 would do. ${ }^{247}$

Absent action from Congress, it is almost certain that courts will continue to be called upon to resolve taxpayer challenges to discriminatory taxation. Our changing economy and the lure of teleworking face off against the increasing revenue needs of states, and the corresponding increase in aggressive collection of taxes from outsiders.

"It is critical to the Union," Douglas Laycock recently urged, "that we continue to think of ourselves as a single people, and it is important that we not knowingly create legitimate interstate grievances. ${ }^{248}$ Discriminatory, or double, taxation of interstate commuters creates genuine grievances, and by allowing those discriminatory taxes to run rampart over interstate commuters, we undermine not only the economy, but also the Union. The Constitution teaches that when state taxing power runs up against preservation of the Union, the Union trumps every time.

247. Telecommuter Tax Fairness Act of 2007, H.R. 1360, 110th Cong. (2007); S. 785, 110th Cong. (2007).

248. Laycock, supra note 22, at 264. 


\title{
Mitchell Hamline Open Access
}

Mitchell Hamline Open Access is the digital archive of Mitchell Hamline School of Law. Its mission is to preserve and provide access to our scholarly activities, for the benefit of researchers and members of the legal community.

Mitchell Hamline Open Access is a service of the Warren E. Burger Library.

open.mitchellhamline.edu

\author{
$\mathrm{MH}$ \\ MITCHELL | HAMLINE \\ School of Law \\ (C) Mitchell Hamline School of Law \\ 875 Summit Avenue, Saint Paul, MN 55105 \\ mitchellhamline.edu
}

